https://doi.org/10.15407/ufm.22.01.129

D.V. ZAGULIAEV ${ }^{1}$, S.V. KONOVALOV ${ }^{2, *}$, Yu.F. IVANOV ${ }^{3}$, V.E. GROMOV ${ }^{1, * * *}$, V.V. SHLYAROV ${ }^{1}$, and YU.A. RUBANNIKOVA ${ }^{1}$

1 Siberian State Industrial University, 42 Kirov Str., 654007 Novokuznetsk, Russian Federation

${ }^{2}$ Academician S.P. Korolyov Samara National Research University, 34 Moskovskoye Shosse, 443086 Samara, Russian Federation

${ }^{3}$ Institute of High-Current Electronics, SB RAS, 2/3 Akademicheskiy Ave., 634055 Tomsk, Russian Federation

*ksv@ssau.ru,** gromov@physics.sibsiu.ru

\title{
THE EFFECT OF HIGH-INTENSITY ELECTRON BEAM ON THE CRYSTAL STRUCTURE, PHASE COMPOSITION, AND PROPERTIES OF AI-Si ALLOYS WITH DIFFERENT SILICON CONTENT
}

The study deals with the element-phase composition, microstructure evolution, crystal-lattice parameter, and microdistortions as well as the size of the coherent scattering region in the $\mathrm{Al}-10.65 \mathrm{Si}-2.11 \mathrm{Cu}$ and $\mathrm{Al}-5.39 \mathrm{Si}-1.33 \mathrm{Cu}$ alloys irradiated with the high-intensity electron beam. As revealed by the methods of x-ray phase analysis, the principal phases in untreated alloys are the aluminium-based solid solution, silicon, intermetallics, and $\mathrm{Fe}_{2} \mathrm{Al}_{9} \mathrm{Si}_{2}$ phase. In addition, the $\mathrm{Cu}_{9} \mathrm{Al}_{4}$ phase is detected in $\mathrm{Al}-10.65 \mathrm{Si}-2.11 \mathrm{Cu}$ alloy. Processing alloys with the pulsed electron beam induces the transformation of lattice parameters of $\mathrm{Al}-10.65 \mathrm{Si}-2.11 \mathrm{Cu}$ (aluminium-based solid solution) and $\mathrm{Al}-5.39 \mathrm{Si}-1.33 \mathrm{Cu}\left(\mathrm{Al}_{1}\right.$ and $\mathrm{Al}_{2}$ phases). The reason for the crystal-lattice parameter change in the $\mathrm{Al}-10.65 \mathrm{Si}-2.11 \mathrm{Cu}$ and $\mathrm{Al}-5.39 \mathrm{Si}-$ $1.33 \mathrm{Cu}$ alloys is suggested to be the changing concentration of alloying elements in the solid solution of these phases. As established, if a density of electron beam is of 30 and $50 \mathrm{~J} / \mathrm{cm}^{2}$, the silicon and intermetallic compounds dissolve in the modified layer. The state-of-the-art methods of the physical materials science made possible to establish the formation of a layer with a nanocrystalline structure of the cell-type crystallization because of the material surface irradiation. The thickness of a modified layer depends on the parameters of the electron-beam treatment and reaches

Citation: D.V. Zaguliaev, S.V. Konovalov, Yu.F. Ivanov, V.E. Gromov, V.V. Shlyarov, and Yu.A. Rubannikova, The Effect of High-Intensity Electron Beam on the Crystal Structure, Phase Composition, and Properties of Al-Si Alloys with Different Silicon Content, Progress in Physics of Metals, 22, No. 1: 129-157 (2021) 
maximum of $90 \mu \mathrm{m}$ at the energy density of $50 \mathrm{~J} / \mathrm{cm}^{2}$. According to the transmission (TEM) and scanning (SEM) electron microscopy data, the silicon particles occupy the cell boundaries. Such changes in the structural and phase states of the materials response on their mechanical characteristics. To characterize the surface properties, the microhardness, wear parameter, and friction coefficient values are determined directly on the irradiated surface for all modification variants. As shown, the irradiation of the material surface with an intensive electron beam increases wear resistance and microhardness of the $\mathrm{Al}-10.65 \mathrm{Si}-2.11 \mathrm{Cu}$ and $\mathrm{Al}-5.39 \mathrm{Si}-1.33 \mathrm{Cu}$ alloys.

Keywords: cast aluminium alloys, electron beam treatment, microstructure, mechanical properties, structure and phase transformations, scanning electron microscopy, transmission electron microscopy, microhardness, tribological testing.

\section{Introduction}

The aluminium and silicon alloy is a commonly used material in motor vehicle and airspace industries due to the excellent correlation between its strength and weight, outstanding castability, low density and sufficient corrosion resistance. Therefore, the $\mathrm{Al}-\mathrm{Si}$ alloys are suitable for the manufacture of high-duty machine elements in motorcar and airplane industries, replacing traditional iron/steel [1-3]. However, Al-Si alloys suffer from certain limitations if compared with the steel, e.g. low strength and wear resistance characteristics of three-dimensional machine elements. It is the reason these alloys can hardly find a broad application. In view of these circumstances, different research groups have attempted to strengthen and modify these alloys as well as develop new technologies of their manufacturing [4, 5]. One of the main current discussions in this field is the effect of intensive plastic deformation on the structure and mechanical properties of alloys, e.g. equal channel angular pressing and equal channel angular extrusion [6-12]. Nevertheless, these methods are not suitable for the strengthening ready to use machine elements, so additional stages are needed in production process chains. In view of this, the diversity of processing techniques have been extensively developed, e.g. the microarc oxidation [13, 14], anodizing [15], plasma electrolytic oxidation [16, 17], plasma spraying [18], and electron beam treatment [19-25] - the surface processing methods, which adapt plasma, particles or electrochemical processes with the purpose to improve the wear resistance and corrosion properties of aluminium.

The surface treatment of metals and alloys with high current electron beams is recognized to be one of the promising and rapidly developing techniques. Within this technological process, accelerated electrons interact with a being processed surface, and as a result, their kinetic energy turns into the heat. A velocity of heating and cooling processes can be rather high (approximately $\sim 10^{6} \mathrm{~K} / \mathrm{s}$ ), cause therefore structure transformations and increase hardness. As a surface modification method, high-current electron-beam treatment is thought to have the advantage 
over laser and pulsed ion processing techniques in terms of efficiency, simplicity, reliability and a beneficial effect on process properties of metallic materials [26-31]. Prior studies on a role of high current electron beams for the structure and physical and mechanical properties of aluminium alloys have pointed out this research domain is of high relevance. Independent groups of scientists have come to a conclusion highcurrent pulsed electron-beam treatment represents a general-purpose technique intended for the improving mechanical properties of $\mathrm{Al}-\mathrm{Si}$ alloys. A number of studies have shown the element composition of the irradiation surface tends to change, thermal instabilities induced by rapid heating and cooling arise in material surface layers. This results into the evaporation and re-precipitation of some amount of alloying elements. A core component of the remelted surface layer is an oversaturated aluminium-based solid solution. The thickness of a remelted zone depends on the number of irradiation impulses. A number of experimental studies have recognized the better corrosion and mechanical properties of alloys treated with high current electron beams [32-38].

The goal of this paper is to explore the structure and phase states, crystal structure, and mechanical characteristics of the $\mathrm{Al}-10.65 \mathrm{Si}-$ $2.11 \mathrm{Cu}$ and $\mathrm{Al}-5.39 \mathrm{Si}-1.33 \mathrm{Cu}$ alloys irradiated with the high current pulsed electron beam.

\section{Material and Methods of Investigation}

We used the cast aluminium $\mathrm{Al}-10.65 \mathrm{Si}-2.11 \mathrm{Cu}$ and $\mathrm{Al}-5.39 \mathrm{Si}-1.33 \mathrm{Cu}$ alloys as an experimental material. This compound is significant for the aluminium alloys of this chemical composition are used in the manufacture of a wide product assortment, e.g. household appliances, products of electrochemical and mechanical engineering. Parallelepiped samples with dimensions of $15 \times 15 \times 5 \mathrm{~mm}^{3}$ were taken for processing and further research.

The chemical composition of as delivered samples determined with the use of $\mathrm{x}$-ray spectrometry is given in Fig. 1. A surface of $15 \times 15$ $\mathrm{mm}^{2}$ samples was polished and mirror-finished for the further electronbeam treatment. The electron beam was moved along the normal line to the polished side of a sample, a diameter of the beam was set to cover the area totally. The alloys were irradiated with the intensive pulsed electron beam using the 'SOLO' laboratory unit [39, 40]. The parameters of the electron beam were as follow: energy of accelerated electrons $17 \mathrm{keV}$; density of the electron beam 10,30 , and $50 \mathrm{~J} / \mathrm{cm}^{2}$; pulse time 50 and $200 \mu \mathrm{s}$; number of pulses 3; pulse repetition frequency $0.3 \mathrm{~s}^{-1}$; and pressure of the residual gas (argon) in the processing chamber of the unit $2 \cdot 10^{-2} \mathrm{~Pa}$. The phase composition was explored with the methods of $\mathrm{x}$-ray phase analysis (Shimadzu x-ray diffractometer XRD 6000). 


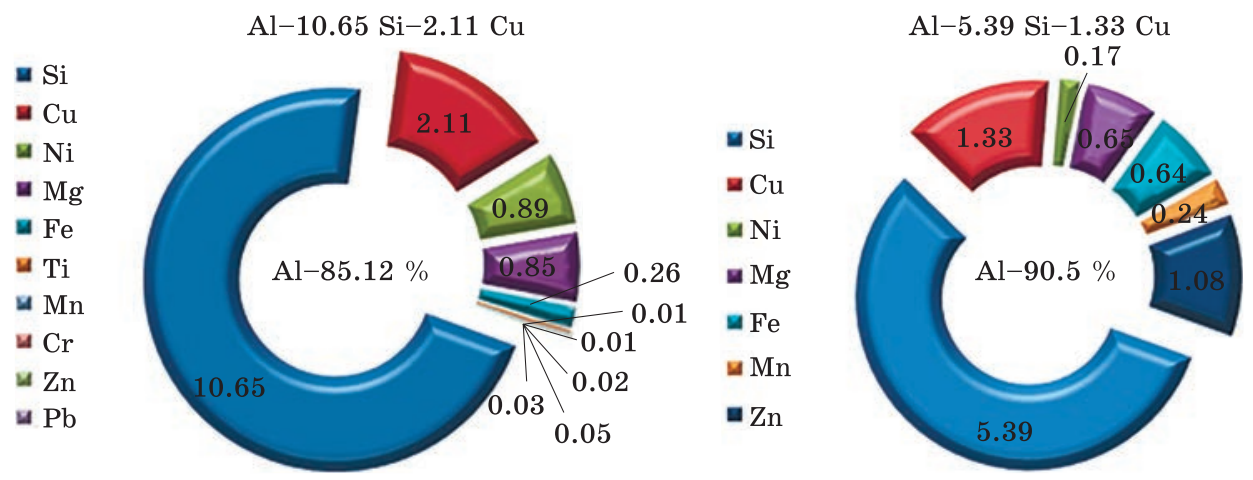

Fig. 1. The percentage of alloying elements and essential impurities in $\mathrm{Al}-10.65 \mathrm{Si}-$ 2.11Cu and $\mathrm{Al}-5.39 \mathrm{Si}-1.33 \mathrm{Cu}$ alloys

The element composition and defect substructure state of alloys were examined using scanning electron microscopy (SEM) (Philips SEM515 equipped with a microanalyser EDAX ECON IV) and transmission electron microscopy (TEM) (JEM 2100F to carry out high-sensitivity electron beam scanning (STEM analysis) and investigate the element composition of foils with the energy-dispersive analysis of $\mathrm{x}$-rays). When carrying out a STEM analysis, the electron beam is focused into a $0.05-$ $0.2 \mathrm{~nm}$ thin spot, further the beam scans a material of interest in the raster lighting system. STEM has the potential to visualize a nanostructured material surface with high spatial resolution and study the distribution of elements in the scanned zone. X-ray crystallography determined a structure state of the $\mathrm{Al}-10.65 \mathrm{Si}-2.11 \mathrm{Cu}$ and $\mathrm{Al}-5.39 \mathrm{Si}-1.33 \mathrm{Cu}$ alloys prior to and after the surface treatment with the intensive electron beam. With the use of this method, the lattice parameter and microdistortions as well as the size of the coherent scattering region were detected. X-ray patterns were produced with a scanning pitch of 0.05 degrees and an exposition time of 5 seconds in each point. Precision shooting of the highlighted $\mathrm{x}$-ray peaks was performed with an interval of 0.02 degrees and an exposition time of 20 seconds. SEM was implemented directly on the treated surface and on etched cross-microsections of irradiated samples. Foils for exploring the structure and phase state of the material with the methods of transmission electron microscopy in the diffraction mode were prepared via ion beam sputtering of plates, which were cut perpendicular to the irradiated surface of a sample using the spark discharge method. A cutting mode was set precisely to avoid unnecessary deformation and therefore have no effect on the structure of a sample.

To characterize mechanical properties of the surface, microhardness testing was chosen in the study for it is one of the most precise and sensitive methods. Measurements were performed with a microhardness- 
measuring device HVS-1000 using the Vickers method [41] and according to ISO 6507-1:2005 'Metallic materials. Vickers hardness test. Part 1. Test method', restoring the indentation made by a four sided squarebased pyramid. Loading was set constant and as high as $0.05 \mathrm{HV}$ for six processing modes. A time a load was applied and kept was $10 \mathrm{~s}$, and within $5 \mathrm{~s}$, a load was removed. Microhardness was determined directly on the modified surface and at different distances from it with a cross microsection.

Tribotechnical studies were implemented as 'pin-on-disc' testing (as specified in ASTM G99) using an Oscillating TRIBOtester (TRIBOtechnic) at load $P=1 \mathrm{~N}$ and sliding speed $V=25 \mathrm{~mm} / \mathrm{s}$. The diameter of a ShKh 15 steel counterbody was $6 \mathrm{~mm}$, sliding distance $S=20 \mathrm{~m}$, and wear track radius $r=2 \mathrm{~mm}$.

\section{Results and Discussion}

\subsection{The Element and Phase Composition, Crystal Structure of Al-Si Alloys Irradiated with the High-Current Pulsed Electron Beam}

The element composition of the material surface was explored after electron beam irradiation. Figure 2 demonstrates the research findings of the $\mathrm{Al}-10.65 \mathrm{Si}-2.11 \mathrm{Cu}$ alloy element composition.

The elemental analysis of $\mathrm{Al}-10.65 \mathrm{Si}-2.11 \mathrm{Cu}$ alloy revealed the electron beam treatment (energy density $10 \mathrm{~J} / \mathrm{cm}^{2}$ and pulse time $50 \mu \mathrm{s}$ ) increases by $53.9 \%$ the silicon concentration in the material surface and its $63.4 \%$ growth was detected, if processed within $200 \mu \mathrm{s}$. A step-up in the beam energy density causes a $10-18 \%$ drop of the silicon concentration in the material surface in relation to process parameters. Another important fact is that the percentage of alloying elements can both fall and rise, depending on parameters of electron beam treatment.

The consideration of the effect of electron-beam treatment had on the silicon concentration in $\mathrm{Al}-5.39 \mathrm{Si}-1.33 \mathrm{Cu}$ alloy brought to light that the irradiation with a $10 \mathrm{~J} / \mathrm{cm}^{2}$ electron beam causes a $47.9-49.2 \%$ growth of a silicon share in the material, irrespectively to the pulse time. A percentage of silicon in the untreated $\mathrm{Al}-5.39 \mathrm{Si}-1.33 \mathrm{Cu}$ alloy is 5.39 wt. $\%$, it increases up to 8.04 wt. $\%$ if irradiated with the electron beam $\left(10 \mathrm{~J} / \mathrm{cm}^{2}, 50 \mu \mathrm{s}\right)$ and to $7.97 \mathrm{wt} . \%$ for a pulse time of $200 \mu \mathrm{s}$. The modification of the alloy surface with the pulsed electron beam heightens also the concentration of copper in the surface by $\approx 115.8 \%$ and iron by $\approx 79.7 \%$.

The outcomes of the elemental analysis of samples irradiated in different modes (Fig. 2 and 3) compared with the data on the chemical composition of untreated materials (Fig. 1) demonstrate that no matter what alloy grade is processed the electron beam density exerts a more 


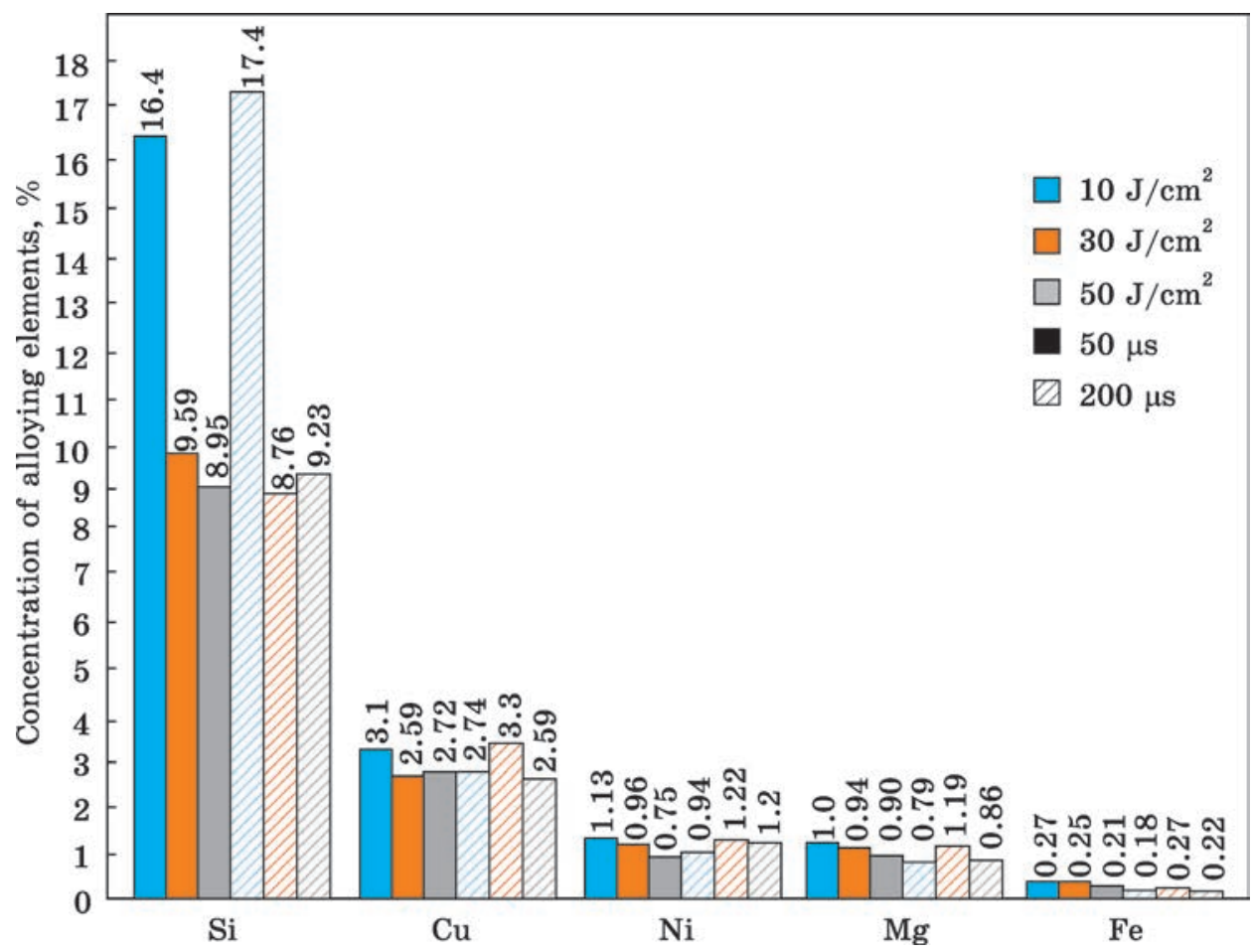

Fig. 2. The percentage of alloying elements and main impurities in $\mathrm{Al}-10.65 \mathrm{Si}-$ $2.11 \mathrm{Cu}$ alloy irradiated with the pulsed electron beam of various energy density and pulse time

significant effect on the element composition of the modified layer than the beam pulse time. The results show the pulsed electron beam (energy density $10 \mathrm{~J} / \mathrm{cm}^{2}$ ) plays the most important role for the silicon concentration in the material surface. This phenomenon is obviously associated with the fact that silicon is a more heat-resistant material than other basic chemical elements in the alloys, and the electron beam energy of $10 \mathrm{~J} / \mathrm{cm}^{2}$ is insufficient to melt it. An increase in the electron beam density up to $30 \mathrm{~J} / \mathrm{cm}^{2}$ and higher dissolves silicon and reduces, therefore, its concentration in the material.

Studies on the phase composition of $\mathrm{Al}-5.39 \mathrm{Si}-1.33 \mathrm{Cu}$ and $\mathrm{Al}-$ $10.65 \mathrm{Si}-2.11 \mathrm{Cu}$ alloys identified that principal phases in the cast materials of interest include an aluminium-based solid solution, silicon and intermetallic compounds, e.g., a $\mathrm{Fe}_{2} \mathrm{Al}_{9} \mathrm{Si}_{2}$ phase. In the $\mathrm{Al}-10.65 \mathrm{Si}-2.11 \mathrm{Cu}$ alloy, there are also $\mathrm{Cu}_{9} \mathrm{Al}_{4}, \mathrm{Cu}_{8.92} \mathrm{Al}_{4.08}, \mathrm{Cu}_{5.64} \mathrm{Al}_{4.61}$ phases undetected in the $\mathrm{Al}-5.39 \mathrm{Si}-1.33 \mathrm{Cu}$ alloy.

An x-ray diffraction pattern of the $\mathrm{Al}-5.39 \mathrm{Si}-1.33 \mathrm{Cu}$ alloy produced in the $\mathrm{x}$-ray phase analysis is provided in Fig. 4. The diffraction maximums of aluminium for the $\mathrm{Al}-5.39 \mathrm{Si}-1.33 \mathrm{Cu}$ alloy show their 


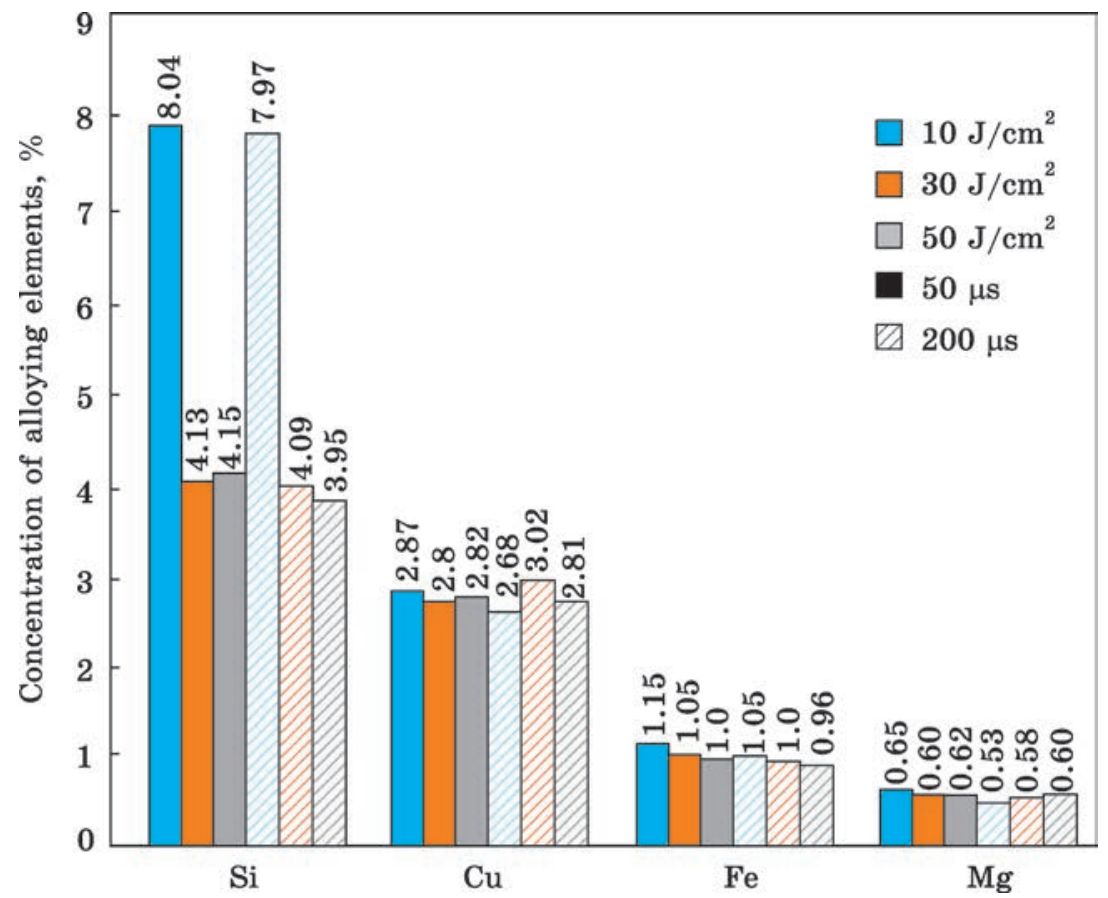

Fig. 3. The percentage of alloying elements and main impurities in $\mathrm{Al}-$ $5.39 \mathrm{Si}-1.33 \mathrm{Cu}$ alloy irradiated with the pulsed electron beam of various energy density and pulse time

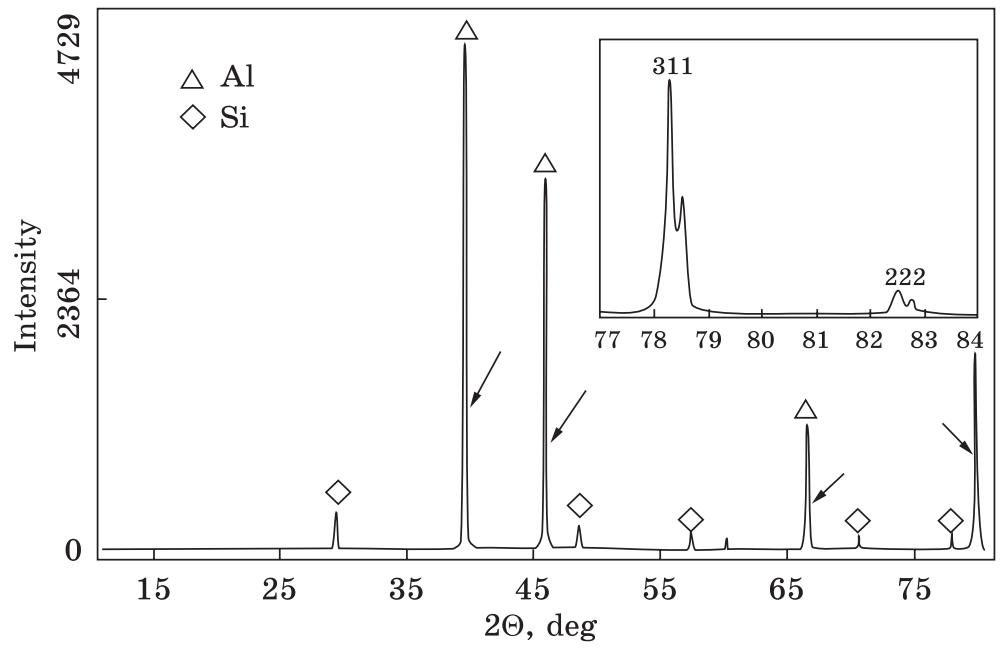

Fig. 4. A fragment of the x-ray diffraction pattern for the untreated $\mathrm{Al}-5.39 \mathrm{Si}-1.33 \mathrm{Cu}$ alloy. Arrows indicate the position of $\mathrm{Al}_{2}$ diffraction lines 


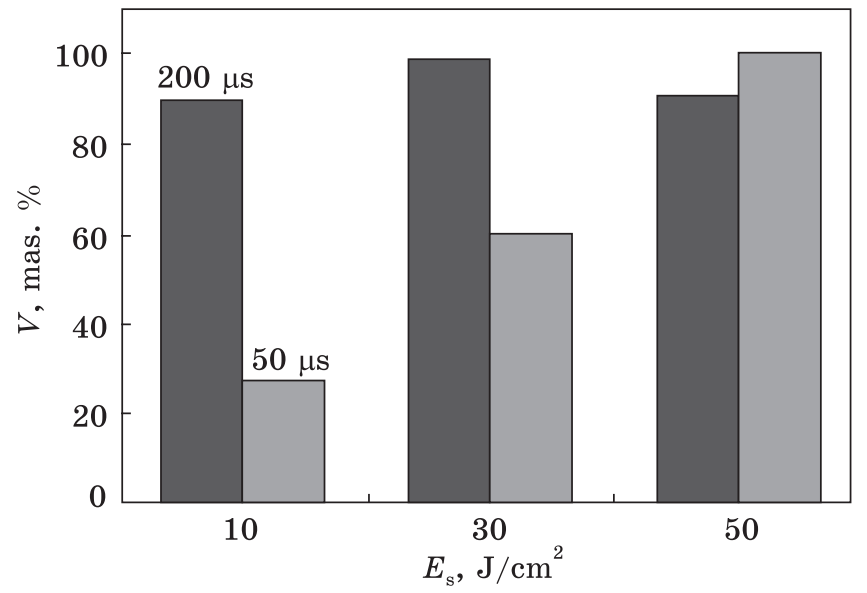

Fig. 5. The percentage of the $\mathrm{Al}_{2}$ phase in the surface layer of $\mathrm{Al}-$ $5.39 \mathrm{Si}-1.33 \mathrm{Cu}$ alloy $v s$. the energy density of electron beam

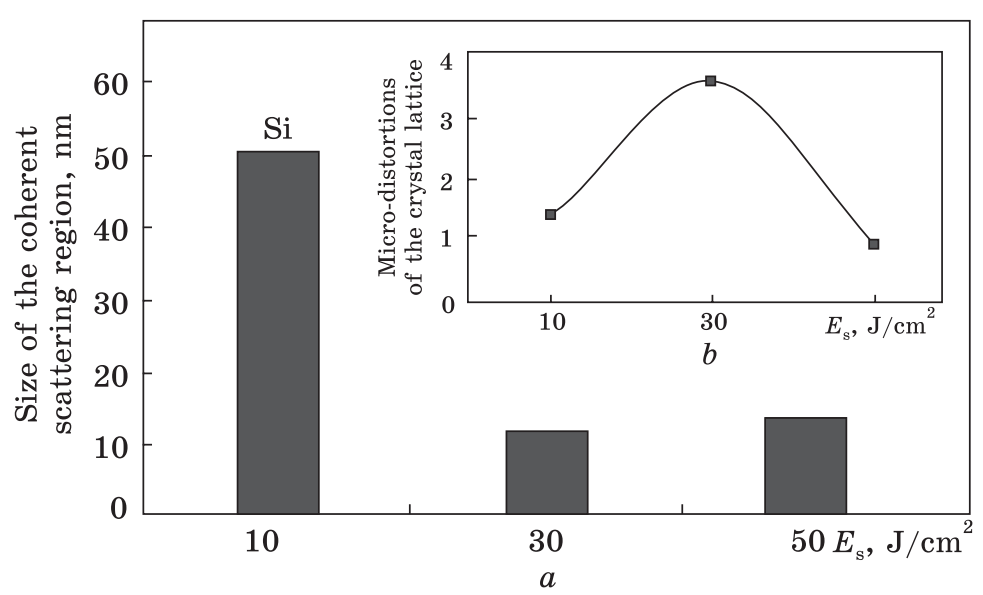

Fig. 6 . The size of the coherent scattering region $(a)$ and microdistortions of the crystal lattice $(b) v s$. the energy density of the electron beam in $\mathrm{Al}-5.39 \mathrm{Si}-1.33 \mathrm{Cu}$ alloy

splitting up (the element added to Fig. 4). These data assume there are two aluminium-based solid solutions with a different lattice parameter. The first type $\mathrm{Al}_{1}$ is an aluminium-based solid solution with a bigger lattice parameter; the second one $\mathrm{Al}_{2}$ has a smaller lattice parameter. Some findings emerging from these data relate to the percentages of $\mathrm{Al}_{1}$ (75.1 mas.\% ), $\mathrm{Al}_{2}$ (20.0 mas.\%), and silicon (the rest) in the $\mathrm{Al}-5.39 \mathrm{Si}-$ $1.33 \mathrm{Cu}$ alloy prior to electron beam irradiation.

Existing research found the relative percentage of the $\mathrm{Al}_{2}$ phase increases if the $\mathrm{Al}-5.39 \mathrm{Si}-1.33 \mathrm{Cu}$ alloy is treated with the pulsed electron beam (pulse time $50 \mu \mathrm{s}$ ) and its energy density is raised (Fig. 5). The percentage of the $\mathrm{Al}_{2}$ phase attains its maximum of $\approx 99$ mas.\% for a pulse time of $200 \mu \mathrm{s}$ and the electron beam energy density of $30 \mathrm{~J} / \mathrm{cm}^{2}$ (Fig. 5). 


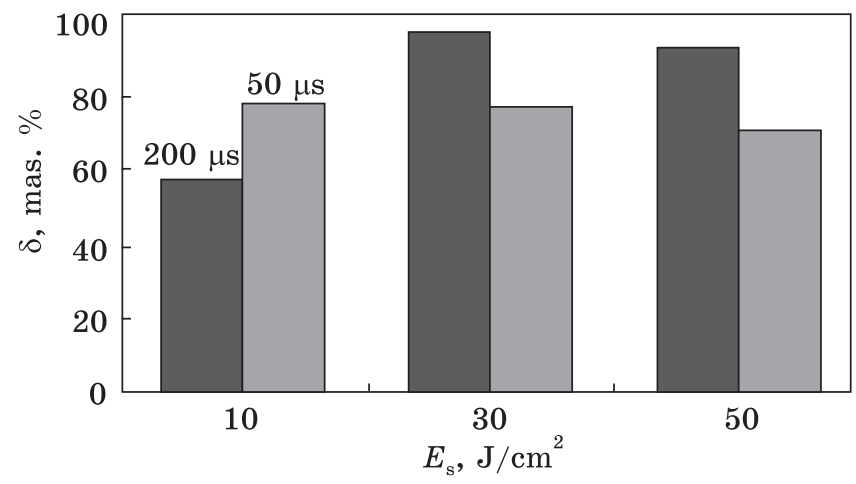

Fig. 7. The percentage of an aluminium-based solid solution in the surface of $\mathrm{Al}-10.65 \mathrm{Si}-2.11 \mathrm{Cu}$ alloy $v s$. the energy density of the electron beam

Studies on the size of the coherent scattering region of $\mathrm{Al}-5.39 \mathrm{Si}-$ $1.33 \mathrm{Cu}$ alloy electrons established it extends to $51.02 \mathrm{~nm}$ for the $\mathrm{Si}$ phase given the electron-beam energy density is $10 \mathrm{~J} / \mathrm{cm}^{2}$ and pulse time is $200 \mu \mathrm{s}$ (Fig. 6,a). A raise of the beam energy density up to $30 \mathrm{~J} / \mathrm{cm}^{2}$ results in the shrinkage of the coherent scattering region to $12.08 \mathrm{~nm}$, whereas it is $1.99 \mathrm{~nm}$ for the beam energy density of $50 \mathrm{~J} / \mathrm{cm}^{2}$. From the data in Fig. 6, $b$, it is apparent the effect is contrary for microdistortions of the Si crystal lattice; that is, they are $1.396 \cdot 10^{-3}$ at $10 \mathrm{~J} / \mathrm{cm}^{2}$, rise up to $3.576 \cdot 10^{-3}$ at $30 \mathrm{~J} / \mathrm{cm}^{2}$ and drop to $0.934 \cdot 10^{-3}$ at $50 \mathrm{~J} / \mathrm{cm}^{2}$.

As observed, the irradiation of the $\mathrm{Al}-10.65 \mathrm{Si}-2.11 \mathrm{Cu}$ alloy with the pulsed electron beam changes the phase composition of the surface. To be more precise, a percentage of an aluminium-based solid solution increases in samples treated with the electron beam (a pulse time of $200 \mu \mathrm{s}$ ) (Fig. 7) and drops in samples irradiated with the electron beam (a pulse time of $50 \mu \mathrm{s}$ ) (Fig. 7) given the density of the electron beam is heightened.

Simultaneously, the content and element composition of hardening phases changes in the surface of the irradiated $\mathrm{Al}-10.65 \mathrm{Si}-2.11 \mathrm{Cu}$ alloy. The data (Fig. 8) demonstrate the silicon percentage decreases and attains its minimum at the energy density of $30 \mathrm{~J} / \mathrm{cm}^{2}$ provided that a pulse time of the electron beam is set $200 \mu$ s and the beam energy density grows (Fig. 8).

The sum total percentage of intermetallic compounds $\left(\mathrm{Cu}_{9} \mathrm{Al}_{4}\right.$, $\mathrm{Cu}_{8.92} \mathrm{Al}_{4.08}, \mathrm{Cu}_{5.64} \mathrm{Al}_{4.61}$ ) also shows a decreasing trend, becoming zero at the energy density of $50 \mathrm{~J} / \mathrm{cm}^{2}$ and a pulse time of the electron beam of $200 \mu$ s (Fig. 8, curve 3). Once a pulse time of the electron beam is $50 \mu \mathrm{s}$, there are opposite changes in the phase composition of the surface. To illustrate, an increase of the beam energy density has an insignificant effect on the silicon percentage (Fig. 8, curve 2). The sum total percentage of intermetallic compounds $\left(\mathrm{Cu}_{8.92} \mathrm{Al}_{4.08}, \mathrm{Cu}_{7} \mathrm{Si}_{12}\right)$ increases and becomes maximal at the energy density of $50 \mathrm{~J} / \mathrm{cm}^{2}$ (Fig. 8, curve 4). 


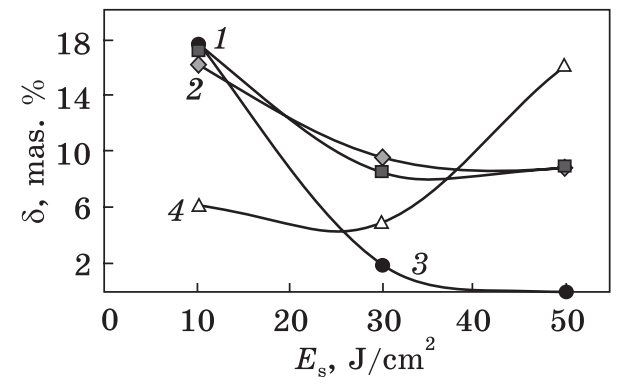

Fig. 8. The role of the beam energy density for the percentage of silicon (curve 1 and 2) and intermetallic compounds (curve 3 and 4 ) in the surface of $\mathrm{Al}-$ 10.65Si-2.11Cu alloy irradiated with the pulsed electron beam; 1 and $3-$ pulse time $200 \mu \mathrm{s} ; 2$ and $4-50 \mu \mathrm{s}$

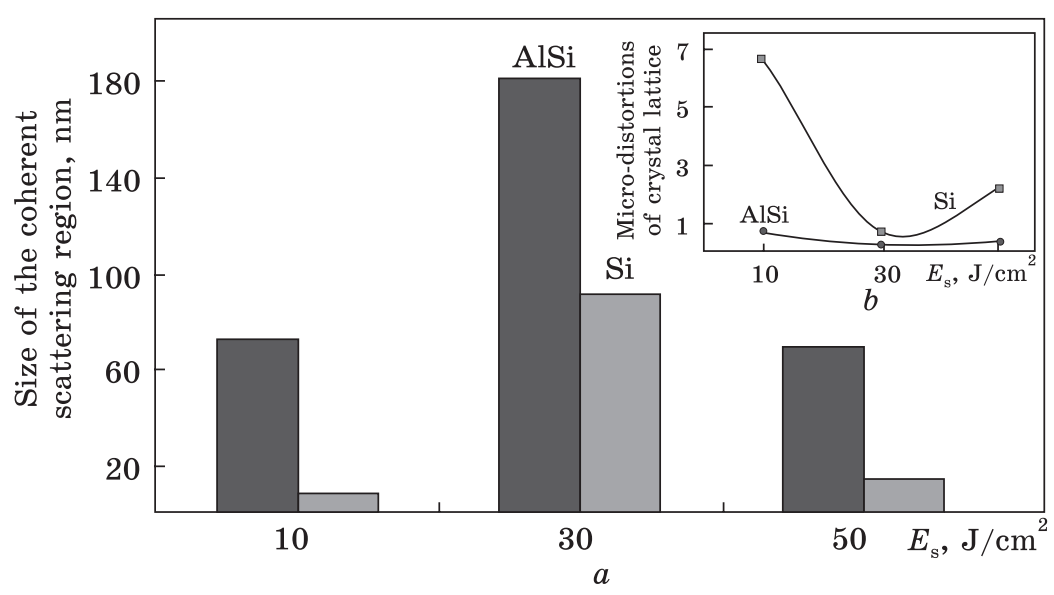

Fig. 9. The size of the coherent scattering region $(a)$ and lattice microdistortions $(b)$ vs. the energy density of electron beam for $\mathrm{Al}-10.65 \mathrm{Si}-$ $2.11 \mathrm{Cu}$

Sizes of the coherent scattering region for the $\mathrm{Al}-10.65 \mathrm{Si}-2.11 \mathrm{Cu}$ alloy were found for two phases - AlSi and Si. The study established the function connecting a size of the coherent scattering region and energy density of the electron beam is a curve with the maximum at $30 \mathrm{~J} / \mathrm{cm}^{2}$ irrespectively to the selected phase (Fig. 9, a). However, the maximal coherent scattering region for $\mathrm{Si}$ is $92.92 \mathrm{~nm}$; that is almost twice as small as the maximal coherent scattering region for the AlSi phase (183.42 nm). The function of lattice microdistortions vs. energy density of the electron beam, on the contrary, is a curve with the minimum observed similarly to the energy density of the electron beam of $30 \mathrm{~J} / \mathrm{cm}^{2}$; it was determined to be $0.744 \cdot 10^{-3}$ for Si and $0.287 \cdot 10^{-3}$ for AlSi (Fig. 10, $b$ ).

The changing phase composition and percentage of phases when irradiating $\mathrm{Al}-5.39 \mathrm{Si}-1.33 \mathrm{Cu}$ and $\mathrm{Al}-10.65 \mathrm{Si}-2.11 \mathrm{Cu}$ alloys with the electron beam are related to transformations in the lattice parameter of the main phase $(\mathrm{Al})$.

Since two phases of aluminium-based solid solutions with different lattice parameters were detected in $\mathrm{Al}-5.39 \mathrm{Si}-1.33 \mathrm{Cu}$, each phase was 


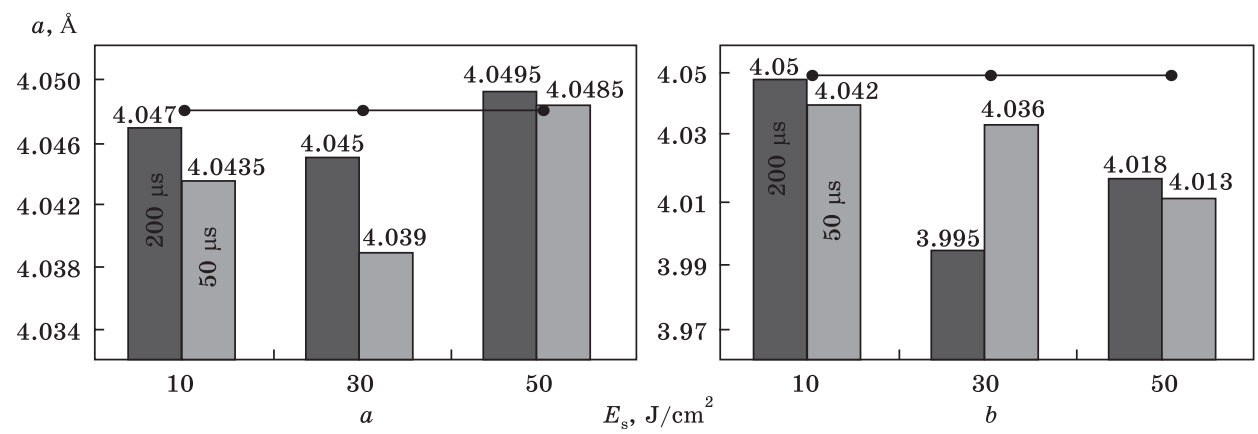

Fig. 10. The lattice parameter of the $\mathrm{Al}_{1}$ phase $(a)$ and $\mathrm{Al}_{2}$ phase $(b)$ forming in the surface layer of $\mathrm{Al}-5.39 \mathrm{Si}-1.33 \mathrm{Cu}$ alloy $v s$. the energy density of electron beam. The unbroken black line indicates the lattice parameter in the untreated alloy

analysed (Fig. 10). The data presented in Fig. 10, $a$ demonstrate the lattice parameter of $\mathrm{Al}_{1}$ is $4.047 \AA$ at the beam energy density of $10 \mathrm{~J} / \mathrm{cm}^{2}$ and a pulse time of $200 \mu \mathrm{s}$, and $4.0435 \AA$ at a pulse time of $50 \mu \mathrm{s}$, respectively. The lattice parameter of the $\mathrm{Al}_{1}$ phase varies as indicated in the graph (Fig. 10, a) and its minimal values are at the beam energy density of $30 \mathrm{~J} / \mathrm{cm}^{2}(4.039 \AA$ for $50 \mu \mathrm{s} ; 4.045 \AA$ for $200 \mu \mathrm{s})$. At the beam energy density of $50 \mathrm{~J} / \mathrm{cm}^{2}$, the lattice parameter of the $\mathrm{Al}_{1}$ phase $(4.0485 \AA$ for $50 \mu \mathrm{s} ; 4.0495 \AA$ for $200 \mu \mathrm{s})$ is higher than the lattice parameter of the $\mathrm{Al}_{1}$ phase in the untreated material (4.048 $\AA$ ).

From the data in Fig. 10, $b$, it is apparent that the lattice parameter of $\mathrm{Al}_{2}$ phase (4.05 $\AA$ ) is similar to this characteristic of the $\mathrm{Al}_{2}$ phase in the untreated material at the beam energy density of $10 \mathrm{~J} / \mathrm{cm}^{2}$ and a pulse time of $200 \mu \mathrm{s}$. As a pulse time is set to $50 \mu \mathrm{s}$, the lattice parameter of the $\mathrm{Al}_{2}$ phase (4.042 $\AA$ ) is lower than this characteristic of the $\mathrm{Al}_{2}$ phase in the untreated alloy. The lattice parameter of the $\mathrm{Al}_{2}$ phase at a pulse time $200 \mu \mathrm{s}$ shows a similar trend as the lattice parameter of the $\mathrm{Al}_{1}$ phase, attaining its lowest value at the beam energy density of $30 \mathrm{~J} / \mathrm{cm}^{2}(3.995 \AA)$. Once a pulse time of the electron beam is $50 \mu \mathrm{s}$, the lattice parameter of the $\mathrm{Al}_{2}$ phase decreases under the rising energy density of the electron beam and becomes minimal $(4.013 \AA)$ at $50 \mathrm{~J} / \mathrm{cm}^{2}$.

The behaviour of the lattice parameter of the aluminium-based solid solution and its dependence on the energy density of the electron beam in the $\mathrm{Al}-10.65 \mathrm{Si}-2.11 \mathrm{Cu}$ alloy is presented in Fig. 11. As seen in Fig. 11, the lattice parameter of aluminium changes irrespectively to the pulse time, its minimums are detected at a pulse time of $200 \mu \mathrm{s}$ $(4.0382 \AA)$ for the energy density of $10 \mathrm{~J} / \mathrm{cm}^{2}$, and at a pulse time of $50 \mu \mathrm{s}(4.0358 \AA)$ for the energy density of $30 \mathrm{~J} / \mathrm{cm}^{2}$.

It is obvious that the principal reason for the mentioned lattice parameter changes of $\mathrm{Al}$ phases no matter which alloy $(\mathrm{Al}-5.39 \mathrm{Si}-1.33 \mathrm{Cu}$ 


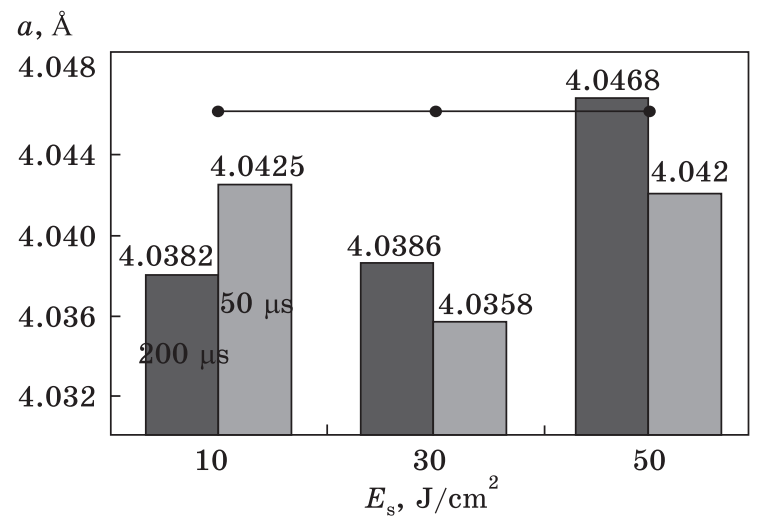

Fig. 11. The lattice parameter of an aluminium-based solid solution forming in the surface of the $\mathrm{Al}-10.65 \mathrm{Si}-2.11 \mathrm{Cu}$ alloy $v$ s. the energy density of electron beam. The solid black line shows the lattice parameter of the phase in the untreated alloy

or $\mathrm{Al}-10.65 \mathrm{Si}-2.11 \mathrm{Cu}$ ) is under study is the varying concentration of alloying elements. As known, the radii of silicon, copper, nickel, iron and manganese atoms are smaller, whereas the magnesium radius is bigger than the radius of the aluminium atom [42]. Therefore, lattice parameters of $\mathrm{Al}$ phases depend on the percentage of these elements in the solid solution. The relation between the lattice parameter of $\mathrm{Al}$ phases and pulse time, energy density of the electron beam is attributed to the dissolution processes of silicon particles and intermetallic compounds, as well as their re-precipitation occurring if a material is irradiated with the pulsed electron beam.

\subsection{Structure Evolution of Al-Si Alloys Irradiated with the High Current Pulsed Electron Beam}

\subsubsection{Studying the Structure of Al-5.39Si-1.33Cu and $\mathrm{Al}-10.65 \mathrm{Si}-2.11 \mathrm{Cu}$ by the SEM Methods}

The SEM-produced images of the untreated material structure are presented in Fig. 12. Dimensionally, aluminium grains are in a range from $25 \mu \mathrm{m}$ to $100 \mu \mathrm{m}$, and the sizes of $\mathrm{Al}-\mathrm{Si}$ eutectics grains varies from 10 to $30 \mu \mathrm{m}$ for the $\mathrm{Al}-10.65 \mathrm{Si}-2.11 \mathrm{Cu}$ alloy. In the $\mathrm{Al}-5.39 \mathrm{Si}-1.33 \mathrm{Cu}$ alloy, an aluminium grain ranges from $25 \mu \mathrm{m}$ to $80 \mu \mathrm{m}$, whereas the size of $\mathrm{Al}-\mathrm{Si}$ eutectics grains is determined to be $11-26 \mu \mathrm{m}$, i.e., the structure elements in both as cast alloys have similar sizes. It is important that there are particles of intermetallic compounds in the alloys, which cause the brittleness of materials under loads.

The SEM of the modified alloy surfaces revealed no significant structural transformations in the $\mathrm{Al}-5.39 \mathrm{Si}-1.33 \mathrm{Cu}$ alloy at the energy density of $10 \mathrm{~J} / \mathrm{cm}^{2}$, and pulse time settings (50 $\mu$ s or $\left.200 \mu \mathrm{s}\right)$ were not critical (Fig. 13, $a$ and $d$ ) if compared to the untreated alloy structure (Fig. 12, a). Micropores and second phase inclusions of a variety of forms and sizes were detected. 

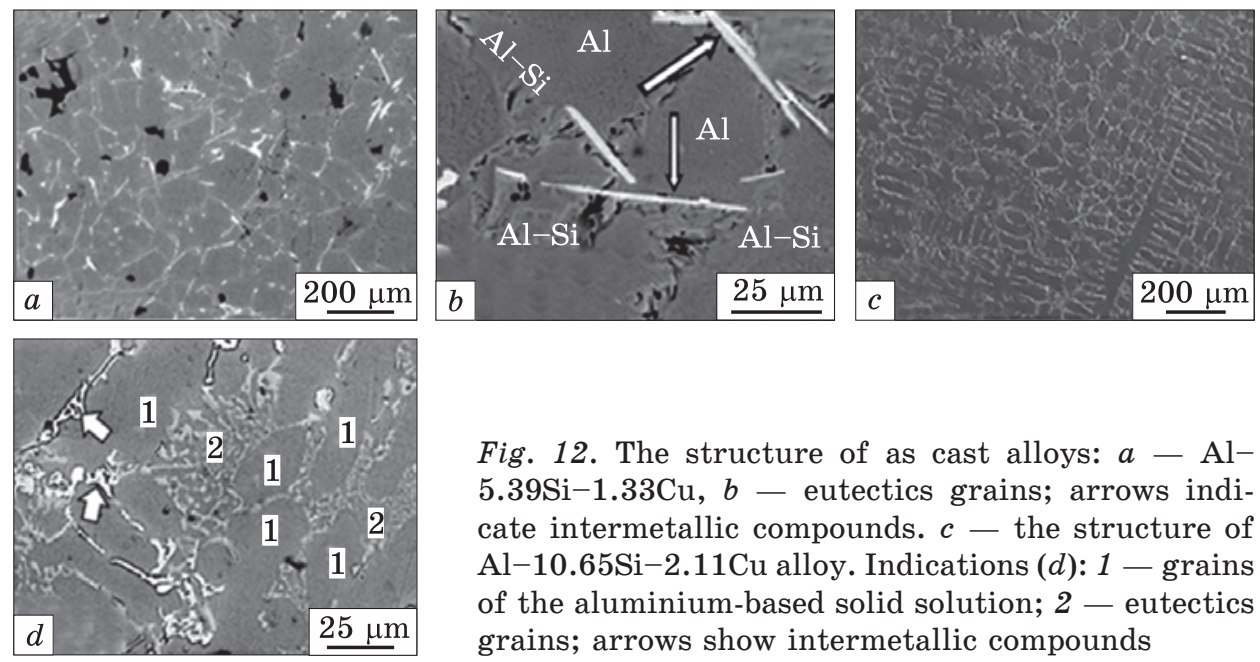

Fig. 12. The structure of as cast alloys: $a-\mathrm{Al}-$ $5.39 \mathrm{Si}-1.33 \mathrm{Cu}, b$ - eutectics grains; arrows indicate intermetallic compounds. $c-$ the structure of $\mathrm{Al}-10.65 \mathrm{Si}-2.11 \mathrm{Cu}$ alloy. Indications $(d): 1$ - grains of the aluminium-based solid solution; 2 - eutectics grains; arrows show intermetallic compounds

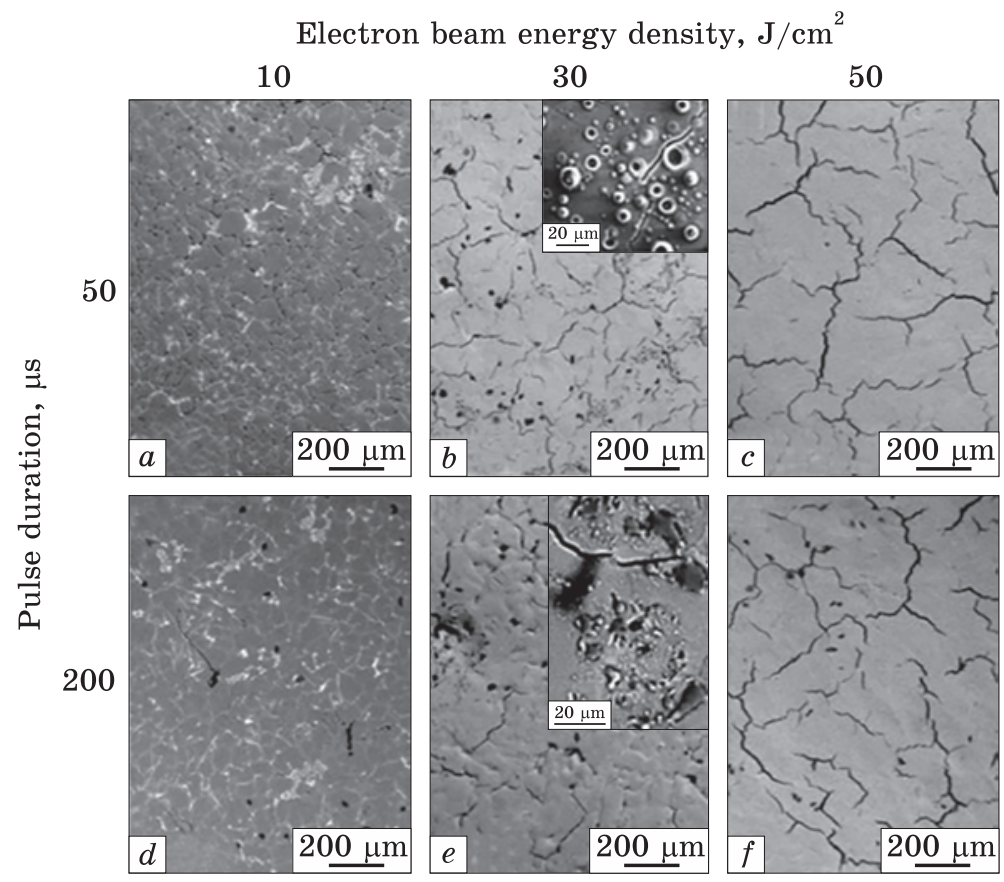

Fig. 13. The surface structure of the $\mathrm{Al}-5.39 \mathrm{Si}-1.33 \mathrm{Cu}$ alloy irradiated with the pulsed electron beam in various modes [43]

When the beam energy density was increased to 30 and $50 \mathrm{~J} / \mathrm{cm}^{2}$, the surface layer experiences essential transformations, i.e., the melting and dissolution of second phase particles, the development of hardening cracks along the grain boundaries. If the energy density of the electron 


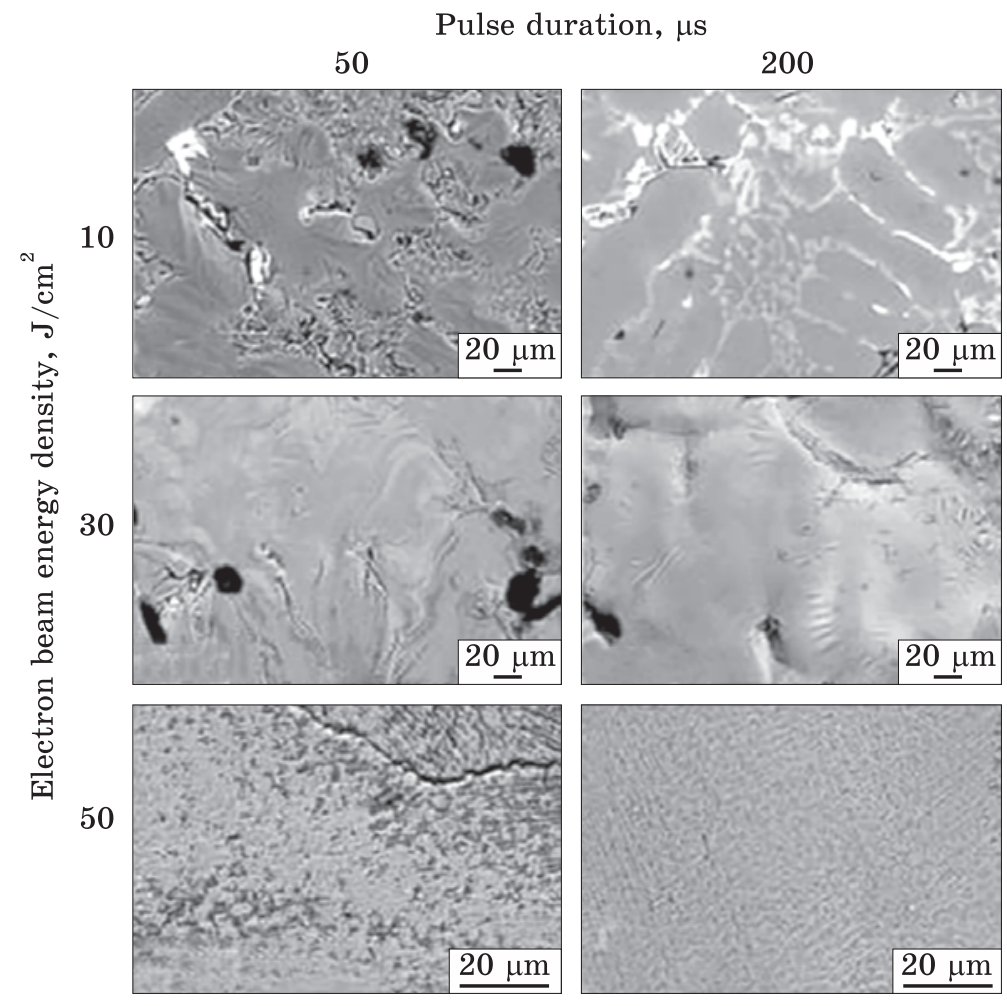

Fig. 14. The structure of $\mathrm{Al}-10.65 \mathrm{Si}-2.11 \mathrm{Cu}$ alloy surface irradiated with the pulsed electron beam in different regimes [44]

beam is of $30 \mathrm{~J} / \mathrm{cm}^{2}$, second phase particles (intermetallic compounds and silicon) fail to dissolve totally. On the irradiated surface, there are regions with microcraters and globular inclusions (see insets in Fig. 13, $b$ and $e$ ). It is interesting that a number of zones with partially dissolved second phase particles and microcraters is higher in the surface layer of samples irradiated with the electron beam of a pulse time of $50 \mu \mathrm{s}$ than in the surface of the $\mathrm{Al}-5.39 \mathrm{Si}-1.33 \mathrm{Cu}$ alloy after irradiating with the electron beam of a pulse time of $200 \mu \mathrm{s}$. The pulse time has virtually no effect on the irradiated surface state at the energy density of the electron beam of $50 \mathrm{~J} / \mathrm{cm}^{2}$. On the treated surface, there are microcracks splitting the surface into regions of tens or hundreds of microns (Fig. $13, c, f)$. Scanning electron microscopy found no second phase particles (intermetallic compounds and silicon).

The SEM of the $\mathrm{Al}-10.65 \mathrm{Si}-2.11 \mathrm{Cu}$ alloy surface irradiated with different values of energy density and pulse time (Fig. 14) shows the treated surface becomes wavy at the beam energy density of $10 \mathrm{~J} / \mathrm{cm}^{2}$; that evidences the beginning of its melting. Similarly to the as cast 


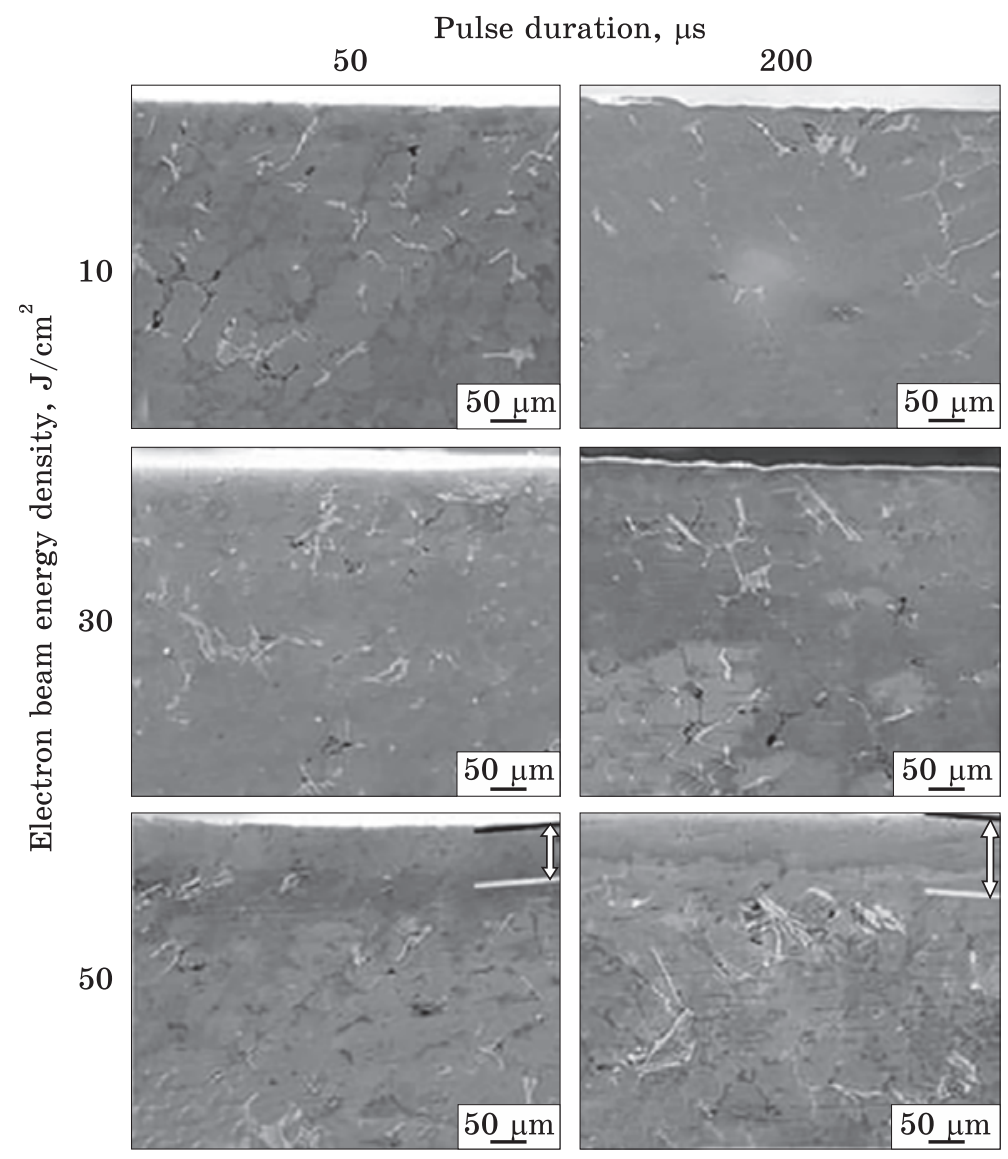

Fig. 15. The structure of the etched $\mathrm{Al}-10.65 \mathrm{Si}-2.11 \mathrm{Cu}$ microsection irradiated with the pulsed electron beam in different regimes [45]

state, the structure has three phases: grains of an aluminium-based solid solution, eutectics grains and intermetallic compounds. At the energy density of $30 \mathrm{~J} / \mathrm{cm}^{2}$, intermetallic compounds dissolve and numerous micropores appear that is probably the consequence of the material shrinkage caused by its rapid solidification. Chaotically located micropores are detected on the irradiated surface at the beam energy density of $50 \mathrm{~J} / \mathrm{cm}^{2}$ irrespectively to the pulse time; they are formed because of inner stresses in the material surface induced by the rapid solidification of the molten layer.

To explore the $\mathrm{Al}-10.65 \mathrm{Si}-2.11 \mathrm{Cu}$ alloy, the SEM was performed on microsections perpendicular to the irradiated surface (Fig. 15).

The data suggest that the thickness of the modified layer correlates with the beam energy density, e.g., $10 \mathrm{~J} / \mathrm{cm}^{2}-1-2 \mu \mathrm{m} ; 30 \mathrm{~J} / \mathrm{cm}^{2}-$ 

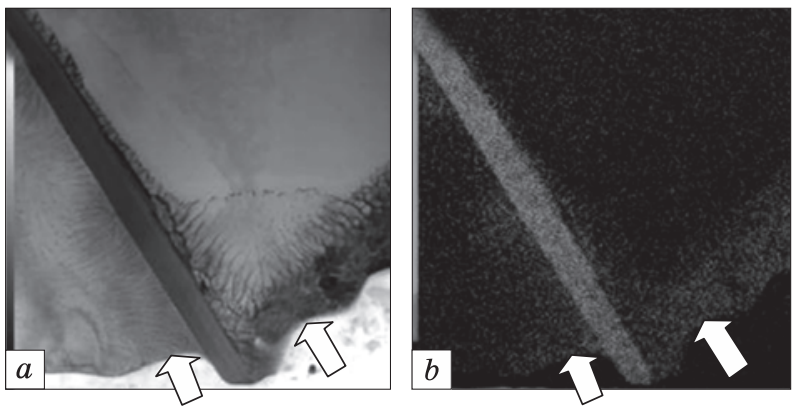

Fig. 16. TEM data of the surface in $\mathrm{Al}-5.39 \mathrm{Si}-1.33 \mathrm{Cu}$ alloy irradiated with the pulsed electron beam $\left(10 \mathrm{~J} / \mathrm{cm}^{2}\right.$, $50 \mu \mathrm{s}, 3$ pulses) $(a)$ and a view of this layer produced in the characteristic $\mathrm{x}$-ray radiation of silicon atoms (b). Arrows indicate the irradiation surface

$25-30 \mu \mathrm{m} ; 50 \mathrm{~J} / \mathrm{cm}^{2}-60-90 \mu \mathrm{m}$. The effect of the electron beam of 30 and $50 \mathrm{~J} / \mathrm{cm}^{2}$ is the dissolution of silicon and intermetallic compounds found in the untreated material; the pulse time is unimportant.

\subsubsection{TEM Analysis of Thin Structure in Al-5.39Si-1.33Cu}

Studies included also the assessment of the thin structure in alloys with the methods of transmission electron microscopy (TEM) before and after irradiating with the pulsed electron beam. Research results show the electron beam modification of the $\mathrm{Al}-5.39 \mathrm{Si}-1.33 \mathrm{Cu}$ alloy with the fixed parameters, $10 \mathrm{~J} / \mathrm{cm}^{2}$ (50 $\mu \mathrm{s}, 3$ pulses), result in a dendrite- and cell-type structure of rapid solidification around silicon lamellae (Fig. 16).

Electron microdiffraction patterns (Fig. 17, b) and dark-field images (Fig. 17, $c, d$ ) show the crystallization cells formed by the aluminium-based solid solution; on the cell boundaries of aluminium, there are particles of silicon.

The crystallization cells are in a range from $40 \mathrm{~nm}$ to $100 \mathrm{~nm}$; the sizes of silicon particles are $5-10 \mathrm{~nm}$. The thin layers of silicon, which form the structure of lamellar eutectics (Fig. 17, $a, d$ ) vary from 15 to $25 \mathrm{~nm}$. Studies established $\mathrm{FeSi}_{2}$ phase lamellae split into several 200 to $300 \mathrm{~nm}$ roundish (globular) fragments in the surface irradiated with the electron beam (Fig. 18).

An increase of the beam energy density up to $30-50 \mathrm{~J} / \mathrm{cm}^{2}$ with no respect to the pulse time $(50 \mu \mathrm{s}$ or $200 \mu \mathrm{s})$ results in a rapid crystallization structure in a 50-70 $\mu \mathrm{m}$ layer. The x-ray spectroscopy shows cells are built by an aluminium-based solid solution; the layers separating crystallization cells contain atoms of silicon, copper, and iron (Fig. 19).

The element composition of a foil section presented in Fig. 19, $a$ is as follows: magnesium (0.85 mas.\%), silicon (2.83 mas.\%), manganese (0.25 mas.\%), iron (0.54 mas.\%), nickel (0.06 mas.\%), and copper (4.07 mas.\%), balanced by aluminium.

A characteristic view of the cell-type crystallization structure produced with the TEM methods is presented in Fig. 20. A dark-field anal- 

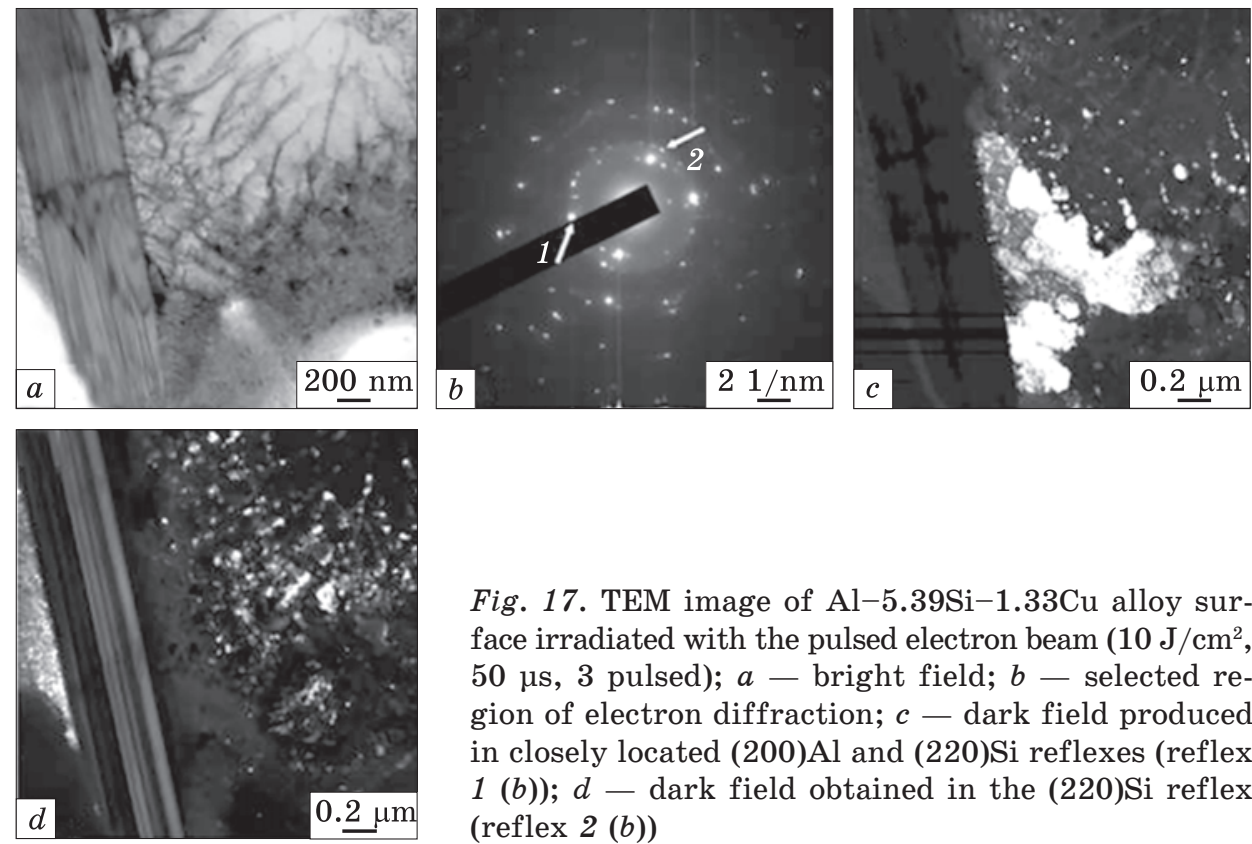

Fig. 17. TEM image of $\mathrm{Al}-5.39 \mathrm{Si}-1.33 \mathrm{Cu}$ alloy surface irradiated with the pulsed electron beam $\left(10 \mathrm{~J} / \mathrm{cm}^{2}\right.$, $50 \mu \mathrm{s}, 3$ pulsed); $a$ - bright field; $b$ - selected region of electron diffraction; $c-$ dark field produced in closely located (200)Al and (220)Si reflexes (reflex $1(b)) ; d-$ dark field obtained in the (220)Si reflex (reflex $2(b))$
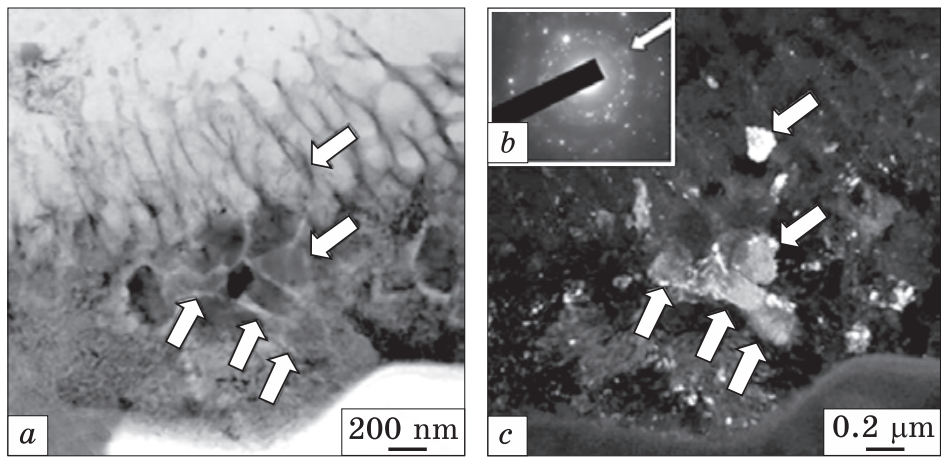

Fig. 18. TEM image of $\mathrm{Al}-5.39 \mathrm{Si}-1.33 \mathrm{Cu}$ alloy surface irradiated with the pulsed electron beam $\left(10 \mathrm{~J} / \mathrm{cm}^{2}, 50 \mu \mathrm{s}, 3\right.$ pulses $) ; a$ - bright field; $b$ - selected region of electron diffraction; $c$ - dark field produced in the (102) $\mathrm{FeSi}_{2}$ reflex (indicated with arrow $(b))$; arrows $(a, c)$ indicate $\mathrm{FeSi}_{2}$ particles

ysis highlights the volume of cells consists of an aluminium-based solid solution (Fig. 20,c). The cells are separated by second-phase particles with 10-20 nm crystallites (Fig. 20, d). A diffraction microanalysis suggests a main element in these crystallites is silicon, however, there can be also complex-composition particles containing copper, iron, silicon, and aluminium atoms. 

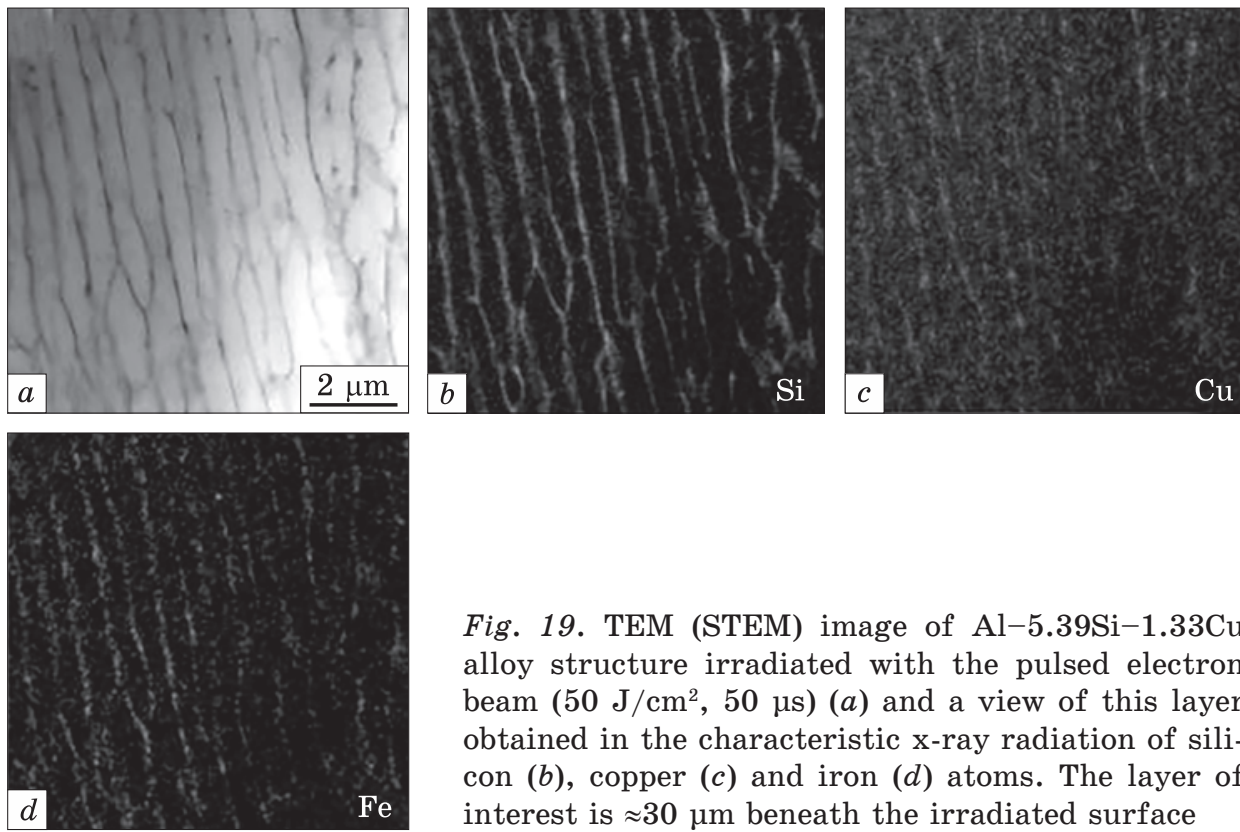

Fig. 19. TEM (STEM) image of $\mathrm{Al}-5.39 \mathrm{Si}-1.33 \mathrm{Cu}$ alloy structure irradiated with the pulsed electron beam $\left(50 \mathrm{~J} / \mathrm{cm}^{2}, 50 \mu \mathrm{s}\right)(a)$ and a view of this layer obtained in the characteristic $\mathrm{x}$-ray radiation of silicon $(b)$, copper $(c)$ and iron $(d)$ atoms. The layer of interest is $\approx 30 \mu \mathrm{m}$ beneath the irradiated surface
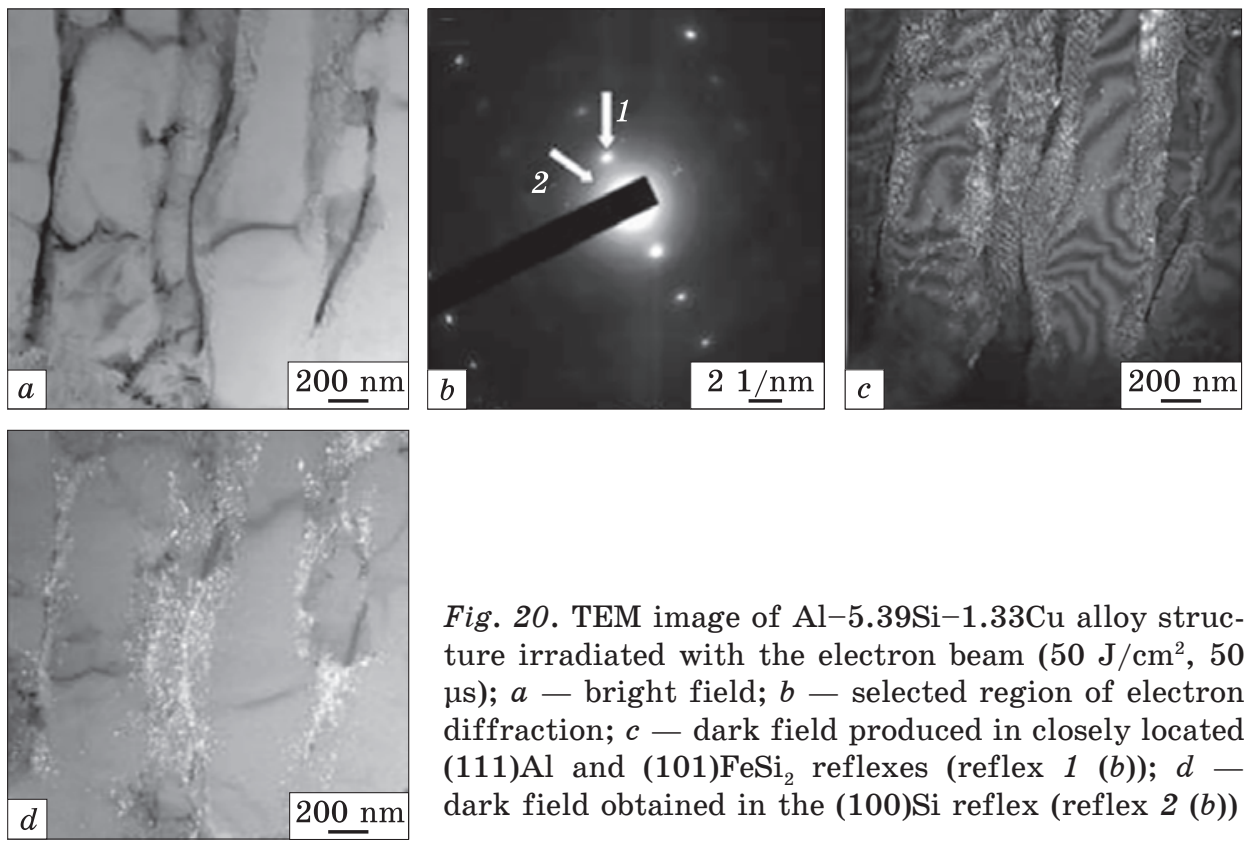

Fig. 20. TEM image of $\mathrm{Al}-5.39 \mathrm{Si}-1.33 \mathrm{Cu}$ alloy structure irradiated with the electron beam $\left(50 \mathrm{~J} / \mathrm{cm}^{2}, 50\right.$ $\mu \mathrm{s}) ; a$ - bright field; $b$ - selected region of electron diffraction; $c$ - dark field produced in closely located (111) $\mathrm{Al}$ and (101) $\mathrm{FeSi}_{2}$ reflexes (reflex $\left.1(b)\right) ; d-$ dark field obtained in the (100)Si reflex (reflex $2(b))$ 


\subsubsection{Studying the Thin Structure in the Al-10.65Si-2.11Cu Exposed to the High Current Pulsed Electron Beam}

A TEM analysis of the $\mathrm{Al}-10.65 \mathrm{Si}-2.11 \mathrm{Cu}$ alloy demonstrates the outcome of the electron beam treatment with the energy density of $10 \mathrm{~J} / \mathrm{cm}^{2}$ (irrespectively to the pulse time of the electron beam) is the melting of aluminium in the most zones of the processed surface. Crystallites of silicon and intermetallic compounds tend to dissolve partially because the electron beam has a weak thermal impact. The STEM studies disclosed a structure forming due to the unfinished dissolution of a silicon crystallite (Fig. 21).

From the data, it is apparent an aluminium structure of the rapid cell-type crystallization is formed after high-velocity heating and cooling (Fig. 21, a). The cell boundaries are surrounded with second phase thin layers containing mostly silicon atoms (Fig. 21,b). Of particular importance is that the thickness of the modified layer surrounding silicon crystallites reduces with distance from the irradiated surface and this layer disappears completely at a depth of 10-12 $\mu \mathrm{m}$. This fact points indirectly at the thickness of a layer where aluminium melts in the contact zone with silicon crystallites.

The outcomes of the electron microscopy diffraction microanalysis carried out on a foil section shown in oval (Fig. 21, a) are given in Fig. 22. As seen from the data in Fig. 22, $a$, the aluminium cells of the rapid crystallization are oval; cross sizes of cells are in a range from $100 \mathrm{~nm}$ to $300 \mathrm{~nm}$ and lengthwise the cells are from $150 \mathrm{~nm}$ to $450 \mathrm{~nm}$. The 40-75 $\mathrm{nm}$ thin second-phase layers surround the cells. The tin layers have a nanosize structure; their crystallites vary from $5 \mathrm{~nm}$ to $10 \mathrm{~nm}$ (Fig. 22,c). The electron diffraction micropattern obtained on this foil section (Fig. 22, $b$ ) shows these thin layers are composed of silicon par-
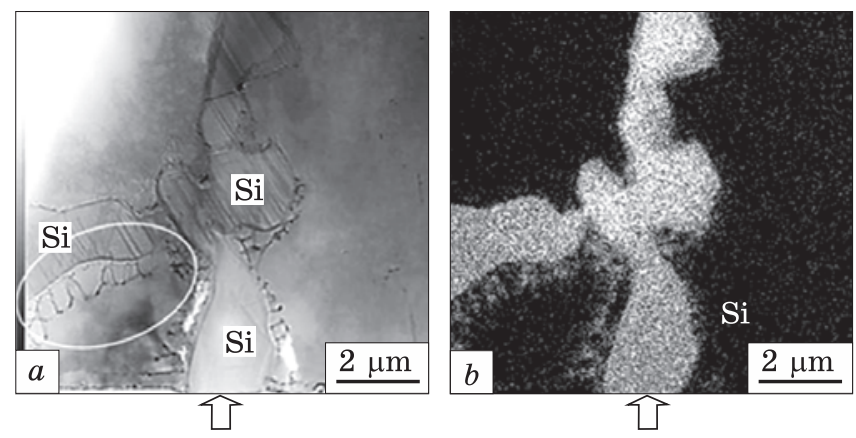

Fig. 21. STEM image $(a)$ and an image produced in the characteristic $\mathrm{x}$-ray radiation of silicon atoms $(b)$ of $\mathrm{Al}-10.65 \mathrm{Si}-2.11 \mathrm{Cu}$ alloy surface irradiated with the pulsed electron beam at the beam energy density of $10 \mathrm{~J} / \mathrm{cm}^{2}, 200 \mu \mathrm{s}$. The arrows indicate the sample surface exposed to irradiation. The oval $(a)$ shows a foil region explored in the electron microscopy diffraction microanalysis [45] 

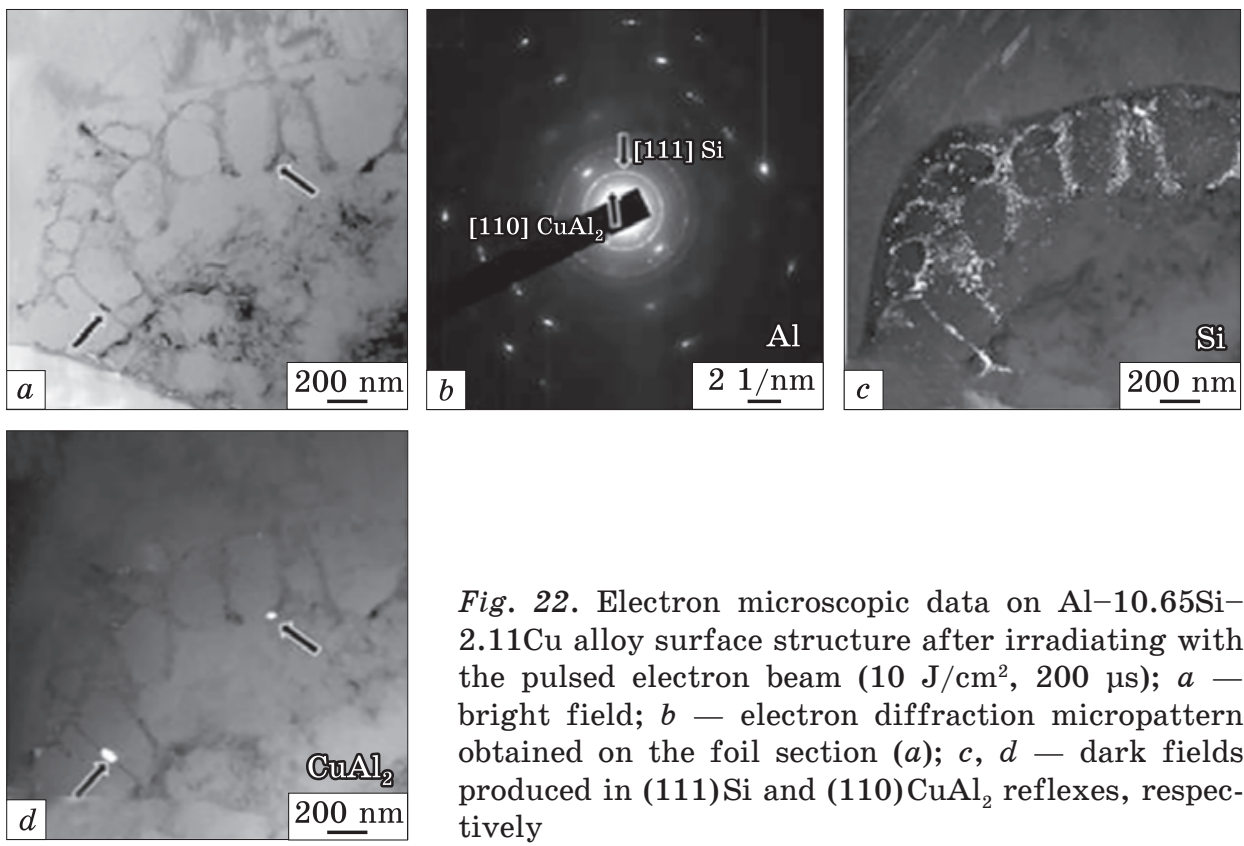

Fig. 22. Electron microscopic data on $\mathrm{Al}-10.65 \mathrm{Si}-$ $2.11 \mathrm{Cu}$ alloy surface structure after irradiating with the pulsed electron beam $\left(10 \mathrm{~J} / \mathrm{cm}^{2}, 200 \mu \mathrm{s}\right) ; a-$ bright field; $b$ - electron diffraction micropattern obtained on the foil section $(a) ; c, d-$ dark fields produced in (111) $\mathrm{Si}$ and (110) $\mathrm{CuAl}_{2}$ reflexes, respectively
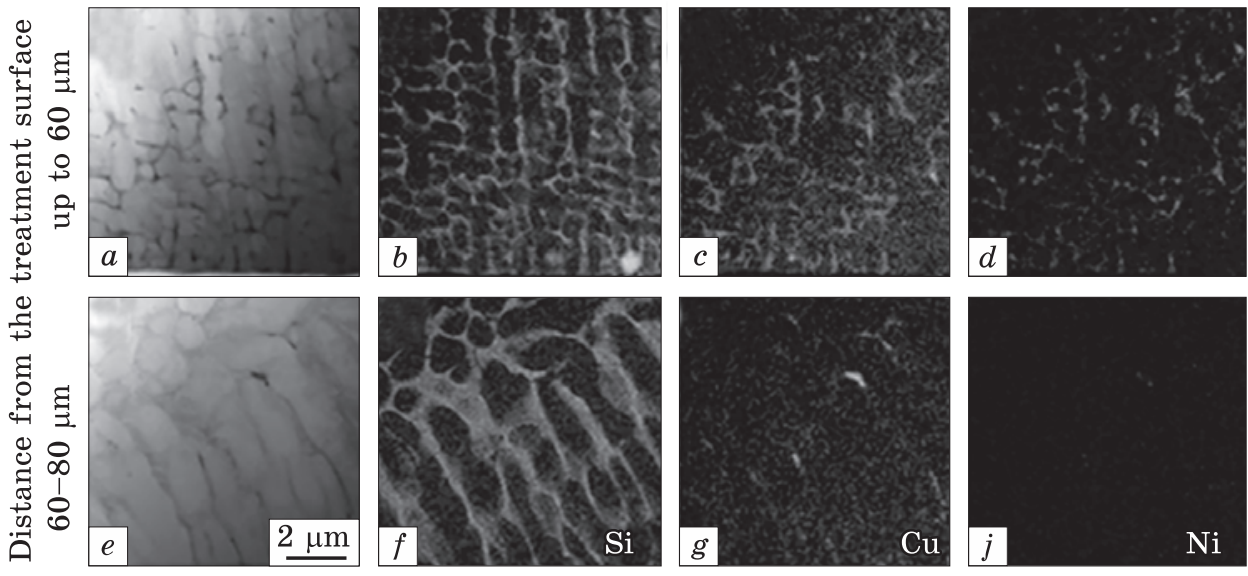

Fig. 23. STEM views $(a, e)$ and data obtained in the characteristic x-ray radiation of silicon $(b, f)$, copper $(c, g)$ and nickel $(d, j)$ atoms of $\mathrm{Al}-10.65 \mathrm{Si}-2.11 \mathrm{Cu}$ alloy surface irradiated with the pulsed electron beam at the beam energy density of $50 \mathrm{~J} / \mathrm{cm}^{2} ; a-d-$ the surface not deeper than $60 \mu \mathrm{m} ; e^{-j}-$ the layer at the depth of 60-80 $\mu \mathrm{m}$ [46]

ticles (Fig. 22, c). Nanosize particles of silicon are detected also within the volume of cells. Besides silicon particles, other phases can form fragments in thin layers. Figure 22, $d$ summarizes the results indicating the $\mathrm{CuAl}_{2}$ phase forming in thin layers. 
The thickness of a layer containing the rapid cell-type crystallization structure increases with the growing energy density of the electron beam (a pulse time is unimportant), and its value is of $\approx 90 \mu \mathrm{m}$ for $50 \mathrm{~J} / \mathrm{cm}^{2}$. The $\mathrm{x}$-ray spectroscopy found out the element composition of thin layers surrounding crystallization cells is connected with the distance to the irradiated surface. In the $60 \mu \mathrm{m}$ surface in thin layers between crystallization cells, there are atoms of silicon, copper, nickel, and an insignificant amount of iron and magnesium (Fig. 23, $a-d$ ). Taking into account the element composition of thin layers, we assume that this layer of the alloy is a result of melting and rapid solidification of all phases constituting the material (aluminium, silicon, intermetallic compounds).

There are atoms of silicon and a small amount of copper $60-80 \mu \mathrm{m}$ below the irradiation surface in thin layers surrounding the rapid solidification cells (Fig. 23,e-j). This layer of the material is suggested to be a product of melting and further rapid solidification of aluminium grains and silicon crystals. Fragments of intermetallic compounds hardly dissolved in this layer.

A structure with silicon crystallites, a cell-type crystallization structure around them and intermetallic compounds are detected 80-90 $\mu \mathrm{m}$ under the irradiation surface. Apparently, the conditions in this layer promote the melting of aluminium and partial dissolution of silicon crystallites. The further rapid solidification resulted in a cell-type crystallization structure in the material close to silicon crystallites. A structure similar to that of the untreated material is found with distance from the irradiated surface.

To sum up, the surface of the $\mathrm{Al}-10.65 \mathrm{Si}-2.11 \mathrm{Cu}$ and $\mathrm{Al}-5.39 \mathrm{Si}-1.33 \mathrm{Cu}$ alloys modified with the intensive pulsed electron beam has a cell-type crystallization structure with a variety of cell sizes. The SEM and TEM studies give the information on silicon particles on the cell boundaries. The cells evidence high velocities of cooling $\sim 10^{6}-10^{7} \mathrm{~K} / \mathrm{s}$. The reason for the columnar crystallization is suggested to be the thermocapillary instability developing because of the temperature gradient in a liquid layer and forcing second-phase particles towards cell boundaries [43-45].

\subsection{Mechanical Characteristics of Al-10.65Si-2.1 $1 \mathrm{Cu}$ and Al-5.39Si-1.33Cu Irradiated with a High Current Pulsed Electron Beam}

Such serious transformations in the structure of materials irradiated with the pulsed electron beam could not be irrelevant for mechanical properties. To characterize surface properties, the microhardness and wear parameter (a reciprocal of wear resistance) were in focus of studies and determined directly on the irradiated surface in all modification 


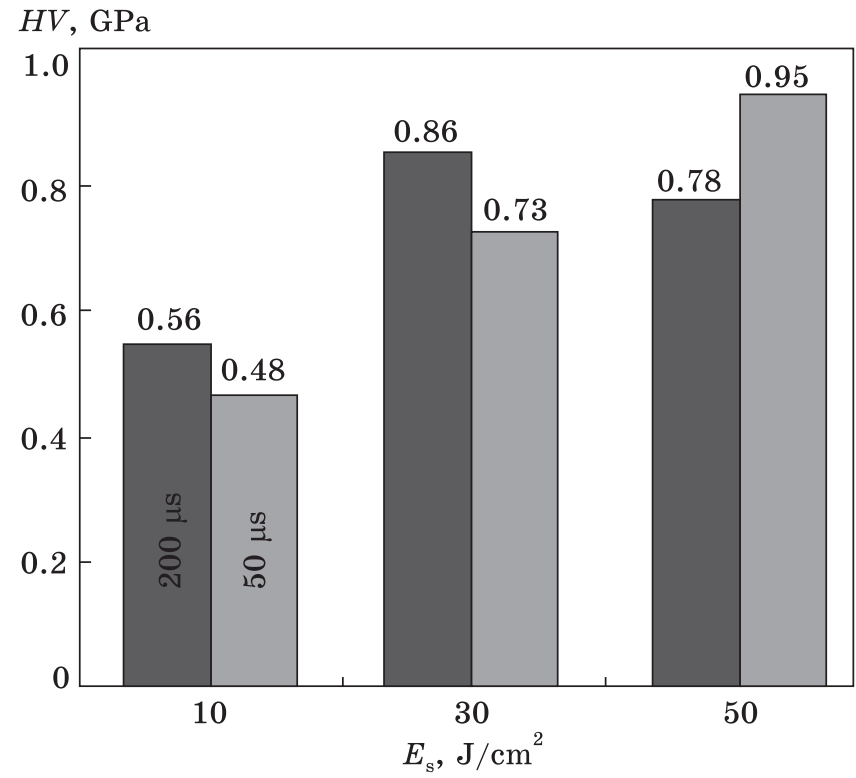

Fig. 24. The microhardness $(H V)$ data $v s$. the energy density of electron beam $(10,30,50 \mathrm{~J} /$ $\left.\mathrm{cm}^{2}\right)$ and pulse time (50 and $200 \mu \mathrm{s})$. The $H V$ value of the as delivered $\mathrm{Al}-5.39 \mathrm{Si}-1.33 \mathrm{Cu}$ alloy is $0.52 \mathrm{GPa}$

modes. The numerical data on the microhardness behaviour in the $\mathrm{Al}-$ $5.39 \mathrm{Si}-1.33 \mathrm{Cu}$ alloy exposed to electron beam treatment are summarized in Fig. 24.

As seen in these data, the microhardness of the surface rises up to $0.95 \mathrm{GPa}$ at the beam energy density of $50 \mathrm{~J} / \mathrm{cm}^{2}$ provided that a pulse time is set $50 \mu$ s and a beam energy density kept increasing; this value is $83 \%$ higher than the same characteristic of the untreated material. Once a pulse time is $200 \mu \mathrm{s}$, the surface microhardness is maximal $(0.86 \mathrm{GPa})$ at the beam energy density of $30 \mathrm{~J} / \mathrm{cm}^{2}$, that is $65 \%$ higher than in the unprocessed material.

The outcomes of tribological testing are presented in Figure 25. It was observed the wear parameter decreases given the energy density of the electron beam is heightened in the irradiation with the electron beam of a pulse time of $200 \mu \mathrm{s}$ (Fig. 25, curve 1). The behaviour of the $\mathrm{Al}-5.39 \mathrm{Si}-1.33 \mathrm{Cu}$ alloy wear resistance is more complex if irradiated with a $50 \mu$ s electron beam (Fig. 25, curve 2). In this case, the wear resistance shows a slightly decreasing trend at the beam energy density of $30 \mathrm{~J} / \mathrm{cm}^{2}$ and rises again if the energy density of the electron beam is set $50 \mathrm{~J} / \mathrm{cm}^{2}$. A maximal increase in wear resistance $\left(k=0.37 \cdot 10^{-3}\right.$ $\mathrm{mm}^{3} / \mathrm{N} \cdot \mathrm{m}$ ) is registered for such treatment parameters as $50 \mathrm{~J} / \mathrm{cm}^{2}$, $200 \mu$ s and amounts to $197 \%$.

The data on the microhardness for the $\mathrm{Al}-10.65 \mathrm{Si}-2.11 \mathrm{Cu}$ alloy irradiated with the pulsed electron beam are summarized in Fig. 26. The bar diagram demonstrates a slight decrease of microhardness if the electron beam with the energy density of $10 \mathrm{~J} / \mathrm{cm}^{2}$ is applied; it may be 


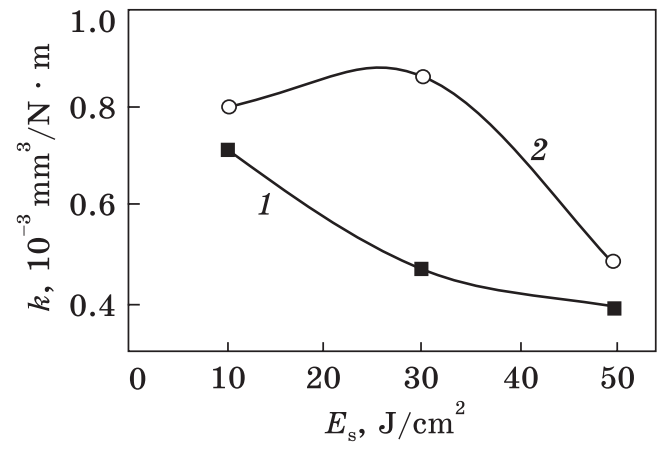

Fig. 25. The wear parameter $k$ vs. the energy density of electron beam (10, $30,50, \mathrm{~J} / \mathrm{cm}^{2}$ ) and pulse time (50 and $200 \mu \mathrm{s})$. The parameter $k$ of the as cast $\mathrm{Al}-5.39 \mathrm{Si}-1.33 \mathrm{Cu}$ alloy is $1.1 \cdot 10^{-3} \mathrm{~mm}^{3} / \mathrm{N} \cdot \mathrm{m} .1-$ pulse time if the electron beam $200 \mu \mathrm{s} ; 2-50 \mu \mathrm{s}$

Fig. 26. The microhardness of $\mathrm{Al}-10.65 \mathrm{Si}-2.11 \mathrm{Cu}$ alloy surface irradiated with the pulsed electron beam (energy density and pulse time are different). The microhardness of the untreated as delivered material is as high as $0.72 \mathrm{GPa}$

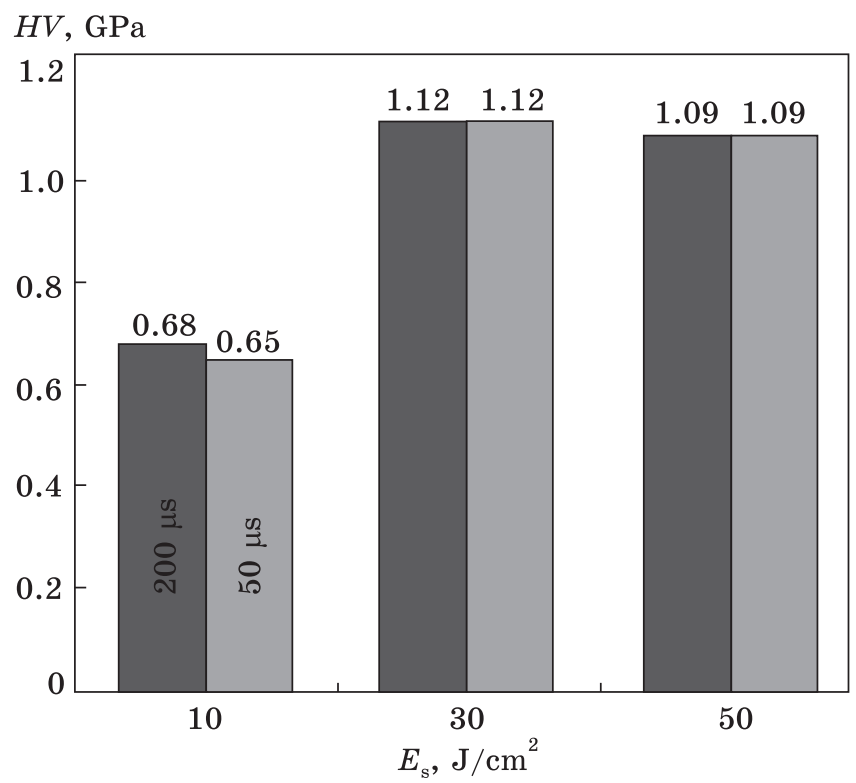

related to the amount of energy transmitted from the beam to the surface, which is insufficient to melt the material and dissolve the intermetallic phase. Microhardness grows to $1.1 \mathrm{GPa}$ on average if the energy density is heightening to $30-50 \mathrm{~J} / \mathrm{cm}^{2}$. Interestingly, there is no found relation between microhardness and pulse time of the electron beam. These transformations appear to be connected with the developing nanocrystalline structure of cell-type crystallization and the dissolving intermetallic phase, as shown by the SEM and TEM methods.

Studies revealed that the friction coefficient and wear intensity (a reciprocal of wear resistance) show a decreasing trend simultaneously to the microhardness growth in irradiated samples. If compared with the untreated material (parameters of tribological testing $P=1 \mathrm{~N}, V=$ $=25 \mathrm{~mm} / \mathrm{s}$ ), the friction coefficient is $\approx 1.3$ times lower and the wear 


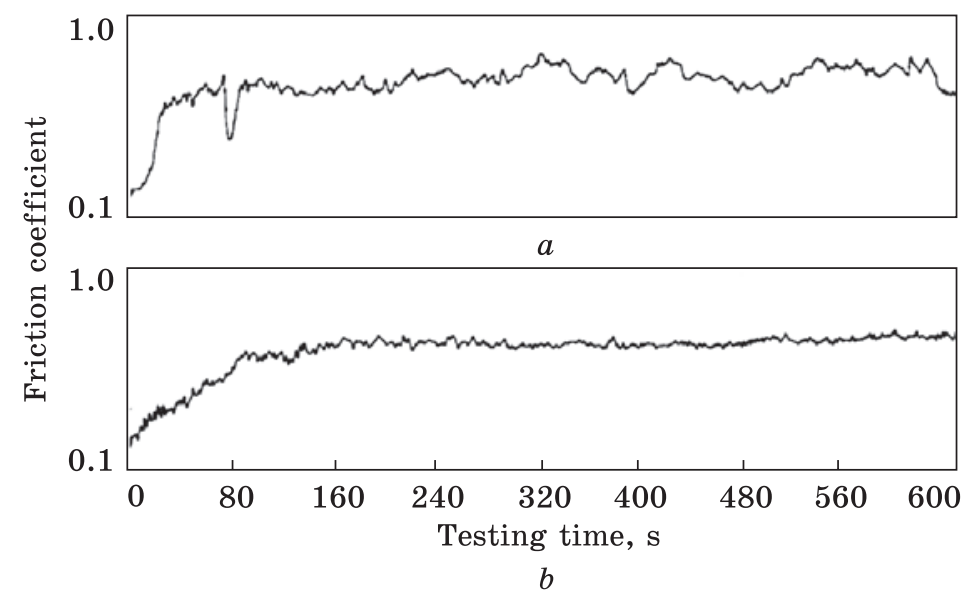

Fig. 27. Friction coefficient $\mu v s$. time of tribological studies on samples of the as cast $\mathrm{Al}-10.65 \mathrm{Si}-2.11 \mathrm{Cu}$ alloy $(a)$ and after irradiating with the intensive pulsed electron beam $(b)$; parameters of tribological testing: $P=1 \mathrm{~N}, V=25 \mathrm{~mm} / \mathrm{s}$ [47]

intensity is $\approx 6.6$ times lower. Figure 27 presents the diagrams characterizing the friction coefficient in tribological tests carried out under lower loads and higher velocity of tribological loading.

The tribological test data of the as cast (Fig. 27, curve $a$ ) and irradiated (Fig. 27, curve b) $\mathrm{Al}-10.65 \mathrm{Si}-2.11 \mathrm{Cu}$ alloy show the friction coefficient of the treated material begins to change in a stationary regime later (minimum $100 \mathrm{~s}$ ), and the peak-to-peak amplitude of friction coefficient in the untreated sample is significantly higher $(\Delta \mu \geq 0.3)$. It may be related to the solidification, breaking-off of hardening particles and to transfer of wear products from the zone of tribological contact onto the counterbody.

The correlation between results of tribological testing and microhardness is suggested, i.e., wear resistance and microhardness increase if the energy density of the electron beam is heightened. Both facts evidence the surface hardening of the material.

\section{Conclusions}

This work was addressed to the element and phase composition, structure and mechanical properties of $\mathrm{Al}-10.65 \mathrm{Si}-2.11 \mathrm{Cu}$ and $\mathrm{Al}-5.39 \mathrm{Si}-1.33 \mathrm{Cu}$ alloy surfaces irradiated with the high intensity electron beam. Several conclusions were formulated in view of the research outcomes.

(i) The principal phases in the untreated alloys of interest include an aluminium-based solid solution, silicon and intermetallic compounds, e.g. a $\mathrm{Fe}_{2} \mathrm{Al}_{9} \mathrm{Si}_{2}$ phase. In the $\mathrm{Al}-10.65 \mathrm{Si}-2.11 \mathrm{Cu}$ alloy, there is also a $\mathrm{Cu}_{9} \mathrm{Al}_{4}$ phase. As established, the treatment transforms the lattice pa- 
rameter of $\mathrm{Al}-10.65 \mathrm{Si}-2.11 \mathrm{Cu}$ (an aluminium-based solid solution) and $\mathrm{Al}-5.39 \mathrm{Si}-1.33 \mathrm{Cu}\left(\mathrm{Al}_{1}\right.$ and $\mathrm{Al}_{2}$ phases $)$ and changes the content of alloying elements in alloy surfaces.

(ii) The coherent scattering region is minimal $(12.08 \mathrm{~nm})$ in the $\mathrm{Al}-5.39 \mathrm{Si}-1.33 \mathrm{Cu}$ alloy (Si phase) for the beam energy density of $30 \mathrm{~J} / \mathrm{cm}^{2}$. Microdistortions of the Si crystal lattice demonstrate the opposite behaviour, increasing up to $3.576 \cdot 10^{-3}$ at $30 \mathrm{~J} / \mathrm{cm}^{2}$.

(iii) The coherent scattering region in the $\mathrm{Al}-10.65 \mathrm{Si}-2.11 \mathrm{Cu}$ alloy was determined for two AlSi and Si phases. The coherent scattering region was found to be maximal at $30 \mathrm{~J} / \mathrm{cm}^{2}$, irrespectively to the phase in focus, it is $92.92 \mathrm{~nm}$ for Si and $183.42 \mathrm{~nm}$ for AlSi. Microdistortions of the crystal lattice show an adverse trend, being a curve with the minimum observed at the beam energy density of $30 \mathrm{~J} / \mathrm{cm}^{2}$.

(iv) The modified layer has a nanocrystalline structure of cell-type crystallization. The thickness of this layer correlated with process parameters. Studies found rapid solidification cells are formed by an aluminium-based solid solution and range from 100 to $450 \mathrm{~nm}$ for $\mathrm{Al}-$ $10.65 \mathrm{Si}-2.11 \mathrm{Cu}$ and from 40 to $100 \mathrm{~nm}$ for $\mathrm{Al}-5.39 \mathrm{Si}-1.33 \mathrm{Cu}$. On the cell boundaries, there are silicon nanocrystallites; their sizes $(5-10 \mathrm{~nm})$ are identical for both alloys of interest.

(v) The microhardness of the $\mathrm{Al}-10.65 \mathrm{Si}-2.11 \mathrm{Cu}$ alloy displays the non-monotonous behaviour; it decreases at the beam energy density of $10 \mathrm{~J} / \mathrm{cm}^{2}$ and rises by $52.8 \%$, if the energy density is set to $30-50 \mathrm{~J} / \mathrm{cm}^{2}$. The friction coefficient is $\approx 1.3$ lower; the wear intensity is $\approx 6.6$ times lower, provided that the microhardness is higher.

(vi) The nanocrystalline structure of cell-type crystallization, which is reinforced with silicon nanocrystals, makes harder the $\mathrm{Al}-5.39 \mathrm{Si}-$ $1.33 \mathrm{Cu}$ alloy surface. A maximal increase of microhardness $(0.95 \mathrm{GPa})$ is observed at the beam energy density of $50 \mathrm{~J} / \mathrm{cm}^{2}$ and a pulse time of $50 \mu \mathrm{s}$. The wear resistance of the $\mathrm{Al}-5.39 \mathrm{Si}-1.33 \mathrm{Cu}$ alloy behaves non-monotonously: decreasing insignificantly at the beam energy density of $30 \mathrm{~J} / \mathrm{cm}^{2}$, but rising if the beam energy density is heightened. A maximal step up $(197 \%)$ of the $\mathrm{Al}-5.39 \mathrm{Si}-1.33 \mathrm{Cu}$ wear resistance $\left(k=0.37 \cdot 10^{-3} \mathrm{~mm}^{3} / \mathrm{N} \cdot \mathrm{m}\right)$ relates to the process parameters $50 \mathrm{~J} / \mathrm{cm}^{2}$ and $200 \mu \mathrm{s}$.

Acknowledgement. The research was granted by the Russian Science Foundation (project No. 19-79-10059).

\section{REFERENCES}

1. V.Ya. Ivanchuk, Tekhnol. Mashinostr., 1: 73 (2001) (in Russian).

2. J.C. Benedyk, Materials, Design and Manufacturing for Lightweight Vehicles (Ed. P.K. Mallick) (Woodhead Publishing Series in Composites Science and Engineering: 2010), p. 79;

https://doi.org/10.1533/9781845697822.1.79 
3. D. Brough and H. Jouhara, Int. J. Thermofluids., 1-2: 100007 (2020); https://doi.org/10.1016/j.ijft.2019.100007

4. Q.G. Wang, Metall. Mater. Trans. A, 34: 2887 (2003); https://doi.org/10.1007/s11661-003-0189-7

5. T. Wei, F. Yan, and J. Tian, J. Alloys \& Compd., 389: 169 (2005); https://doi.org/10.1016/j.jallcom.2004.05.084

6. M. Liu, J. Chen, Y. Lin, Z. Xue, H.J. Roven, and P.C. Skaret, Prog. Nat. Sci. Mater. Int., 30: 485 (2020); https://doi.org/10.1016/j.pnsc.2020.07.005

7. C. Rochet, E. Andrieu, B. Arfaei, J.-P. Harouard, A. Laurino, T.C. Lowe, G. Odemer, and C. Blanc, Int. J. Fatigue, 140: 105812 (2020); https://doi.org/10.1016/j.ijfatigue.2020.105812

8. V. Andreyachshenko, Mater. Lett., 254: 433 (2019); https://doi.org/10.1016/j.matlet.2019.07.127

9. K. Natori, H. Utsunomiya, and T. Tanaka, J. Mater. Process. Technol., 240: 240 (2017); https://doi.org/10.1016/j.jmatprotec.2016.09.022

10. Z. Zribi, H.H. Ktari, F. Herbst, V. Optasanu, and N. Njah, Mater Charact., 153: 190 (2019);

https://doi.org/10.1016/j.matchar.2019.04.044

11. M. Ebrahimi, M.H. Shaeri, R. Naseri, and C. Gode, Mater. Sci. Eng. A, 731: 569 (2018);

https://doi.org/10.1016/j.msea.2018.06.080

12. M. Hockauf, L.W. Meyer, B. Zillmann, M. Hietschold, S. Schulze, and L. Krüger, Mater. Sci. Eng. A, 503: 167 (2009);

https://doi.org/10.1016/j.msea.2008.02.051

13. W. Xue, X. Shi, M. Hua, and Y. Li, Appl. Surf. Sci., 253: 6118 (2007); https://doi.org/10.1016/j.apsusc.2007.01.018

14. N.Y. Dudareva, L.I. Zaynullina, and E.I. Ustimova, Mater. Today Proc., 11: 181 (2019); https://doi.org/10.1016/j.matpr.2018.12.128

15. M. Mohedano, E. Matykina, R. Arrabal, B. Mingo, and A. Pardo, Appl. Surf. Sci., 346: 57 (2015); https://doi.org/10.1016/j.apsusc.2015.03.206

16. K. Li, W. Li, G. Zhang, W. Zhu, F. Zheng, D. Zhang, and M. Wang, J. Alloys \& Compd., 790: 650 (2019); https://doi.org/10.1016/j.jallcom.2019.03.217

17. J. He, Q.Z. Cai, H.H. Luo, L. Yu, and B.K. Wei, J. Alloys \& Compd., 471: 395 (2009); https://doi.org/10.1016/j.jallcom.2008.03.114

18. P. He, L. Tang, G. Ma, H. Wang, S. Chen, M. Liu, S. Ding, Y. Bai, J.Tang, and D. He, Appl. Surf. Sci., 530: 147246 (2020); https://doi.org/10.1016/j.apsusc.2020.147246

19. H. Bian, K. Aoyagi, Y. Zhao, C. Maeda, T. Mouri, and A. Chiba, Addit. Manuf., 32: 100982 (2020); https://doi.org/10.1016/j.addma.2019.100982

20. W. Shaogang, H. Yan, and Z. Li, Met. Mater. Eng., 47, No. 7: 1973 (2018). https://doi.org/10.1016/S1875-5372(18)30167-X

21. Yu.F. Ivanov, V.E. Gromov, D.V. Zagulyaev, S.V. Konovalov, Yu.A. Rubannikova, and A. P. Semin, Prog. Phys. Met., 21, No. 3: 345 (2020);

https://doi.org/10.15407/ufm.21.03.345 
22. Yu.F. Ivanov, V.E. Gromov, D.V. Zagulyaev, S.V. Konovalov, Yu.A. Rubannikova, and A.P. Semin, Prog. Phys. Met., 20, No. 4: 634 (2019);

https://doi.org/10.15407/ufm.20.04.634

23. Yu.F. Ivanov, D.V. Zagulyaev, S.A. Nevskii, V.E. Gromov, V.D. Sarychev, and A.P. Semin, Prog. Phys. Met., 20, No. 3: 447 (2019); https://doi.org/10.15407/ufm.20.03.447

24. Yu.F. Ivanov, V.E. Gromov, S.V. Konovalov, D.V. Zagulyaev, E.A. Petrikova, and A.P. Semin, Prog. Phys. Met., 19, No. 2: 195 (2018); https://doi.org/10.15407/ufm.19.02.195

25. V. E. Kormyshev, V.E. Gromov, Yu.F. Ivanov, and S.V. Konovalov, Usp. Fiz. Met., 18, No. 2: 111 (2017) (in Russian); https://doi.org/10.15407/ufm.18.02.111

26. A.D. Teresov, V.V. Shugurov, Yu.F. Ivanov, Yu.A. Denisova, E.A. Petrikova, and N.N. Koval', Izvestiya Vuzov. Fizika, 58: 112 (2015) (in Russian).

27. V.A. Shulov, A.N. Gromov, D.A. Teryaev, and V.I. Engel'ko, Izvestiya Vuzov. Poroshkovaya Metallurgiya i Funktsional'nyye Pokrytiya, No. 1: 38 (2015) (in Russian); https://doi.org/10.17073/1997-308X-2015-1-38-48

28. V.A. Shulov, V.I. Engelko, A.N. Gromov, D.A. Teryaev, O.A. Bytsenko, and G.G. Shivaryants, Physics and Chemistry of Materials Treatment, No. 5: 22 (2015) (in Russian).

29. T.C. Zhang, K.M. Zhang, J.X. Zou, P. Yan, H.Y. Yang, L.X. Song, and X. Zhang, $J$ Alloys \& Compd., 788: 231 (2019); https://doi.org/10.1016/j.jallcom.2019.02.130

30. X. Zhang, K. Zhang, J. Zou, P. Yan, L. Song, and Y. Liu, Vacuum, 173: 109132 (2020); https://doi.org/10.1016/j.vacuum.2019.109132

31. L. Wang, K. Wang, N. Erkan, Y. Yuan, J. Chen, B. Nie, F. Li, and K. Okamoto, Appl. Surf. Sci., 511: 145555 (2020); https://doi.org/10.1016/j.apsusc.2020.145555

32. P. Yu, M. Yan, D. Tomus, C.A. Brice, C.J. Bettles, B. Muddle, and M. Qian, Mater. Charact., 143: 43 (2018); https://doi.org/10.1016/j.matchar.2017.09.005

33. B. Gao, N. Xu, and P. Xing, Mater Lett., 237: 180 (2019); https://doi.org/10.1016/j.matlet.2018.11.054

34. H. Li, W. Xu, Z. Wang, B. Fang, R. Song, and Z. Zheng, Mater. Sci. Eng. A, 650: 254 (2016); https://doi.org/10.1016/j.msea.2015.10.051

35. P. Yan, T. Grosdidier, X. Zhang, and J. Zou, Mater. Design, 159: 1 (2018); https://doi.org/10.1016/j.matdes.2018.08.033

36. P. Yan, J. Zou, C. Zhang, and T. Grosdidier, Appl. Surf. Sci., 504: 144382 (2020); https://doi.org/10.1016/j.apsusc.2019.144382

37. B. Gao, Y. Hao, W.F. Zhuang, G.F. Tu, W.X. Shi, S.W. Li, S.Z. Hao, C. Dong, and M.C. Li, Phys. Procedia, 18: 187 (2011); https://doi.org/10.1016/j.phpro.2011.06.079

38. J. An, X.X. Shen, Y. Lu, Y.B. Liu, R.G. Li, C.M. Chen, and M.J. Zhang, Surf. Coatings Technol., 200, Nos. 18-19: 5590 (2006);

https://doi.org/10.1016/j.surfcoat.2005.07.106

39. N.N. Koval' and Y.F. Ivanov, Russ Phys. J., 51: 505 (2008); https://doi.org/10.1007/s11182-008-9073-7 
40. D. Zaguliaev, S. Konovalov, Y. Ivanov, and V. Gromov, Appl. Surf. Sci., 498: 143767 (2019); https://doi.org/10.1016/j.apsusc.2019.143767

41. B. Daemi, R. Tomkowski, and A. Archenti, CIRP Ann., 69, No. 1: 433 (2020); https://doi.org/10.1016/j.cirp.2020.03.022

42. A.P. Babichev, O.N. Babushkina, and A.M. Bratkovsky, Fizicheskie Velichiny: Spravochnik [Physical Values: Reference Book] (Moscow: Energoatomizdat: 1991) (in Russian).

43. D. Zaguliaev, I. Chumachkov, Y. Ivanov, A. Abaturova, A. Ustinov, and A. Semin, 2020 7th International Congress on Energy Fluxes and Radiation Effects (EFRE) (14-26 Sept. 2020, Tomsk, Russia) (IEEE: 2020), p. 737; https://doi.org/10.1109/EFRE47760.2020.9242140

44. S. Konovalov, D. Zaguliaev, Y. Ivanov, V. Gromov, and A. Abaturova, J. Mater. Res. Technol., 9, No. 3: 5591 (2020); https://doi.org/10.1016/j.jmrt.2020.03.083

45. D. Zaguliaev, S. Konovalov, Y. Ivanov, A. Abaturova, and A. Leonov, Arch. Foundry Eng., 20, No. 3: 92 (2020); https://doi.org/10.24425/afe.2020.133336

46. V.V. Shlyarov, D.V. Zaguliaev, A.A. Abaturova, A.A. Leonov, and A.M. Ustinov, Basic Problems of Material Science, 17, No. 1: 32 (2020) (in Russian); https://doi.org/10.25712/ASTU.1811-1416.2020.01.005

47. D.V. Zagulyaev, V.E. Gromov, S.V. Konovalov, A.M. Glezer, S.V. Panin, and Yu.F. Ivanov, Russ. Metall., 2019: 981 (2019); https://doi.org/10.1134/S0036029519100318

Received 08.12.2020; in final version, 19.02.2021

Д.В. Загуляєв ${ }^{1}$, С.В. Коновалов ${ }^{2}$ Ю.Ф. Іванов $^{3}$, В.С. Громов ${ }^{1}$ В.В. Шляров ${ }^{1}$ Ю.А. Рубаннікова ${ }^{1}$

${ }^{1}$ Сибірський державний індустріальний університет, вул. Кірова, 42, 654007 Новокузнецьк, Російська Федерація

${ }^{2}$ Самарський національний дослідницький університет імені академіка С.П. Корольова, Московське шосе, 34, 443086 Самара, Російська Федерація

${ }^{3}$ Інститут сильнострумової електроніки СВ РАН, просп. Академічний, 2/3, 634055 Томськ, Російська Федерація

ВПЛИВ ВИСОКОІНТЕНСИВНОГО ЕЛЕКТРОННОГО ПУЧКА НА КРИСТАЛІЧНУ БУДОВУ, ФАЗОВИЙ СКЛАД І ВЛАСТИВОСТІ CTOПIB Al-Si 3 РІЗНИМ ВМІСТОМ СИЛІЦІЮ

Роботу спрямовано на вивчення елементного та фазового складу, мікроструктурної еволюції, параметра та мікроспотворень кристалічної гратниці та розміру ділянки когерентного розсіяння у стопах $\mathrm{Al}-10,65 \mathrm{Si}-2,11 \mathrm{Cu}$ i $\mathrm{Al}-5,39 \mathrm{Si}-1,33 \mathrm{Cu}$, оброблюваних високоінтенсивним електронним пучком. Методами рентгенофазової аналізи встановлено, що у вихідному стані основними фазами досліджуваних стопів є твердий розчин на основі алюмінію, силіцій та інтерметаліди, а також наявна фаза складу $\mathrm{Fe}_{2} \mathrm{Al}_{9} \mathrm{Si}_{2}$. У стопі $\mathrm{Al}-10,65 \mathrm{Si}-2,11 \mathrm{Cu}$ додатково виявлено фазу $\mathrm{Cu}_{9} \mathrm{Al}_{4}$. Опромінення стопів імпульсним електронним пучком супроводжується зміною параметра кристалічної гратниці $\mathrm{Al}-10,65 \mathrm{Si}-2,11 \mathrm{Cu}$ (твердий розчин на основі алюмінію) та $\mathrm{Al}-5,39 \mathrm{Si}-1,33 \mathrm{Cu}$ (фази $\mathrm{Al}_{1}$ i $\mathrm{Al}_{2}$ ). Ймовірно, причиною зміни параметра кристалічної гратниці в стопах $\mathrm{Al}-10,65 \mathrm{Si}-2,11 \mathrm{Cu}$ та 
$\mathrm{Al}-5,39 \mathrm{Si}-1,33 \mathrm{Cu}$ є зміна концентрації легувальних елементів у твердому розчині даних фаз. Встановлено, що при густині пучка електронів у 30 і 50 Дж/см² у модифікованому шарі спостерігається розчинення силіцію та інтерметалідів. Сучасні методи фізичного матеріялознавства уможливили встановити, що в результаті опромінення поверхні матеріялу формується шар з нанокристалічною структурою коміркової кристалізації. Товщина модифікованого шару варіюється залежно від параметрів електронно-пучкового оброблення й сягає максимального значення у 90 мкм за густини енергії у 50 Дж/ $\mathrm{cm}^{2}$. За даними сканувальної (CEM) та просвітлювальної (ПЕМ) електронної мікроскопії частинки силіцію розташовуються на межах комірок. Подібні зміни структурно-фазових станів матеріялів позначаються й на механічних характеристиках. У якості характеристики поверхневих шарів використовували мікротвердість, параметр зношення та коефіцієнт тертя, значення яких визначали безпосередньо на поверхні опромінення, для всіх варіянтів модифікування. Показано, що при оброблянні поверхні матеріялу інтенсивним імпульсним електронним пучком відбувається збільшення зносостійкости та мікротвердости стопів $\mathrm{Al}-10,65 \mathrm{Si}-2,11 \mathrm{Cu}$ i $\mathrm{Al}-5,39 \mathrm{Si}-1,33 \mathrm{Cu}$.

Ключові слова: виливані алюмінійові стопи, електронно-пучкове оброблення, мікроструктура, механічні властивості, структурно-фазові перетворення, сканувальна електронна мікроскопія, просвітлювальна електронна мікроскопія, мікротвердість, трибологічні випробування. 